\title{
Review
}

\section{The Role of Oxidative Stress in Parkinson's Disease}

\author{
Vera Dias, Eunsung Junn and M. Maral Mouradian* \\ Center for Neurodegenerative and Neuroimmunologic Diseases, Department of Neurology, Rutgers - Robert Wood \\ Johnson Medical School, Piscataway, NJ, USA
}

\begin{abstract}
Oxidative stress plays an important role in the degeneration of dopaminergic neurons in Parkinson's disease (PD). Disruptions in the physiologic maintenance of the redox potential in neurons interfere with several biological processes, ultimately leading to cell death. Evidence has been developed for oxidative and nitrative damage to key cellular components in the PD substantia nigra. A number of sources and mechanisms for the generation of reactive oxygen species (ROS) are recognized including the metabolism of dopamine itself, mitochondrial dysfunction, iron, neuroinflammatory cells, calcium, and aging. PD causing gene products including DJ-1, PINK1, parkin, alpha-synuclein and LRRK2 also impact in complex ways mitochondrial function leading to exacerbation of ROS generation and susceptibility to oxidative stress. Additionally, cellular homeostatic processes including the ubiquitin-proteasome system and mitophagy are impacted by oxidative stress. It is apparent that the interplay between these various mechanisms contributes to neurodegeneration in PD as a feed forward scenario where primary insults lead to oxidative stress, which damages key cellular pathogenetic proteins that in turn cause more ROS production. Animal models of PD have yielded some insights into the molecular pathways of neuronal degeneration and highlighted previously unknown mechanisms by which oxidative stress contributes to PD. However, therapeutic attempts to target the general state of oxidative stress in clinical trials have failed to demonstrate an impact on disease progression. Recent knowledge gained about the specific mechanisms related to PD gene products that modulate ROS production and the response of neurons to stress may provide targeted new approaches towards neuroprotection.
\end{abstract}

Keywords: Neurodegeneration, neuroprotection, neuroinflammation, reactive oxygen species, dopamine, mitochondria

\section{INTRODUCTION}

The mechanisms responsible for neuronal degeneration in Parkinson's disease (PD) are complex and remain to be fully elucidated. Among the various neuronal types that degenerate in this disease, there is little doubt that the loss of dopaminergic neurons in the substantia nigra pars compacta ( $\mathrm{SNpc}$ ) is responsible for the characteristic motor symptoms and drives symptomatic therapies [1, 2]. Accumulating evidence indicates that oxidative damage and mitochondrial dysfunction contribute to the cascade of events leading to degeneration of these dopaminergic

\footnotetext{
*Correspondence to: M. Maral Mouradian, Rutgers - RWJMS, 683 Hoes Lane West, Room 180, Piscataway, NJ 08854, USA. Tel.: +1 732235 4772; Fax: +1 732235 4773; E-mail: m.mouradian@ rutgers.edu.
}

neurons [3-7]. This is supported by postmortem brain analyses showing increased levels of 4-hydroxyl-2nonenal (HNE), a by-product of lipid peroxidation [8, 9], carbonyl modifications of soluble proteins [10], and DNA and RNA oxidation products 8-hydroxydeoxyguanosine and 8-hydroxy-guanosine [11, 12]. The link between oxidative stress and dopaminergic neuronal degeneration is further supported by modeling the motor aspects of PD in animals with toxins that cause oxidative stress including 1-methyl-4-phenyl1,2,3,6-tetrahydropyridine (MPTP), rotenone, 1,1'dimethyl-4,4'-bipyridinium dichloride (paraquat), and 6-hydroxydopamine (6-OHDA) [13-17]. In addition to $\mathrm{PD}$, several other neurodegenerative disorders including Alzheimer's disease, Huntington's disease, and amyotrophic lateral sclerosis are associated with oxidative stress as well, despite having distinct 
pathological and clinical features [18] suggesting that oxidative stress is a common mechanism contributing to neuronal degeneration $[19,20]$.

Here we review the role of oxidative stress in the pathogenesis of PD, its effects on cellular homeostasis, the biochemical and molecular events that mediate or regulate neuronal vulnerability, and the role of PD-related gene products in modulating the cellular responses to oxidative stress in the course of neurodegeneration.

\section{THE BIOCHEMISTRY OF OXIDATIVE STRESS}

Oxidative stress defines a disequilibrium between the levels of reactive oxygen species (ROS) produced and the ability of a biological system to detoxify the reactive intermediates, creating a perilous state contributing to cellular damage.

ROS can be generated through several pathways such as direct interactions between redox-active metals and oxygen species via reactions including the Fenton and Haber-Weiss reactions, or by indirect pathways involving the activation of enzymes such as nitric oxide synthase (NOS) or NADPH oxidases. As a general principle, the chemical origin of the majority of free radicals requires the activation of molecular oxygen [21]. Examples of ROS include the superoxide anion radical $\left(\mathrm{O}_{2}{ }^{2-}\right)$, hydroxyl radical $\left({ }^{\bullet} \mathrm{OH}\right)$ and hydrogen peroxide $\left(\mathrm{H}_{2} \mathrm{O}_{2}\right)$. Superoxide anion, which is produced mainly by mitochondrial complexes I and III of the electron transport chain, is highly reactive and can easily cross the inner mitochondrial membrane, where it can be reduced to $\mathrm{H}_{2} \mathrm{O}_{2}$. Besides being produced by mitochondria, $\mathrm{H}_{2} \mathrm{O}_{2}$ can also be generated by peroxisomes [22]. As peroxisomes contain catalase, $\mathrm{H}_{2} \mathrm{O}_{2}$ is converted to water, preventing its accumulation. However, when peroxisomes are damaged and their enzymes down-regulated, $\mathrm{H}_{2} \mathrm{O}_{2}$ is released to the cytosol where it contributes to oxidative stress. In the presence of reduced metals such as ferrous iron $\left(\mathrm{Fe}^{2+}\right), \mathrm{H}_{2} \mathrm{O}_{2}$ can be converted by the Fenton reaction into the highly reactive hydroxyl radical, the most harmful of all ROS [23].

Besides ROS, evidence also exists for the involvement of reactive nitrogen species (RNS) in mediating nitrosative stress [24]. RNS are generated by the quick reaction of superoxide with nitric oxide (NO), which results in the production of large amounts of peroxynitrite $\left(\mathrm{ONOO}^{-}\right)$) [25, 26]. NO is produced by NO synthase (NOS) [27], which has three isoforms, endothelial NOS (eNOS), neuronal NOS (nNOS) identified in neurons, and inducible NOS (iNOS) identified in glial cells [27-29]. NO is present within cells and in the extracellular space surrounding dopaminergic neurons produced by either nNOS or iNOS [30]. Additionally, with gliosis, activated glial cells that express iNOS may contribute to increased NO levels $[31,32]$. NO inhibits several enzymes including complexes I and IV of the mitochondrial electron transport chain, leading to ROS generation. It also reacts with proteins to form S-nitrosothiols thus altering their function, and with lipids causing their lipid peroxidation [25]. Peroxynitrite, which is oxidatively a more active molecule and a more potent oxidizing agent than NO, can induce DNA fragmentation and lipid peroxidation $[25,26]$. Peroxynitrite also induces a dose-dependent impairment in dopamine synthesis independent of dopamine oxidation or cell death [26]. Exposure of tyrosine hydroxylase $(\mathrm{TH})$, the rate-limiting enzyme in dopamine synthesis, to peroxynitrite results in nitration of tyrosine residues and modification of cysteines leading to decreased catalytic activity [33, 34]. The role of NO in PD is supported by postmortem brain tissue analyses showing increased expression of iNOS and nNOS in basal ganglia structures using in situ hybridization and immunohistochemical studies [35, 36]. Experimentally in the MPTP model, the gliosis in the $\mathrm{SN}$ is associated with significant up-regulation of iNOS [37], while inhibition of nNOS protects against MPTP toxicity [38, 39]. Together, these observations suggest that $\mathrm{NO}$ and its metabolite peroxynitrite may play a role in PD.

All organisms have developed adaptive responses to oxidative stress that result in increased production of defensive enzymes, molecular chaperones and antioxidant molecules [40]. Under physiologic conditions, ROS are involved in signaling events mediated by thiol residues in proteins that have the potential to regulate transcription [41]. On the other hand, under conditions of oxidative stress, free radical-mediated oxidative damage occurs at various sites within the cell such as peroxidation of cellular membrane lipids resulting in the generation of toxic products including HNE and malondialdehyde [9], protein oxidation demonstrated by cross-linking and fragmentation as well as carbonyl group formation [10, 42], and DNA and RNA oxidation [11].

\section{ROS PRODUCTION IN THE PD BRAIN}

The extensive production of ROS in the brain may provide an explanation for the magnitude of the role that these reactive molecules play in PD. The brain consumes about $20 \%$ of the oxygen supply of the body, 
and a significant portion of that oxygen is converted to ROS [43]. ROS can be generated in the brain from several sources, both in neurons and glia, with the electron transport chain being the major contributor at the mitochondrial level $[44,45]$. Other ROS sources include monoamine oxidase (MAO), NADPH oxidase (NOX) and other flavo-enzymes along with NO, which is abundant in the brain due to the presence of NOS [43]. Considerable experimental evidence suggests that a significant contributor to dopaminergic neuronal loss in the PD brain is ROS, which result from dopamine metabolism, low glutathione (GSH), and high levels of iron and calcium in the SNpc [6]. Additionally, the brain contains high concentrations of polyunsaturated fatty acids, which under oxidative stress conditions result in lipid peroxidation and the generation of toxic products [46].

\section{Dopamine}

Dopamine is an unstable molecule that undergoes auto-oxidation to form dopamine quinones and free radicals. This reaction is catalyzed by metals, oxygen or enzymes such as tyrosinase [47]. Other enzymes, such as MAO and catechol O-methyl transferase (COMT) are also involved in dopamine metabolism. MAO-A and MAO-B, located in the outer mitochondrial membrane, degrade excess dopamine in the cytosol by catalyzing its oxidative deamination [48].

Under normal conditions, dopamine levels are regulated through oxidative metabolism by MAO$\mathrm{A}$, which is mostly localized in catecholaminergic neurons [49]. However, with neuronal degeneration that occurs in PD and aging, MAO-B located in glial cells increases and becomes the predominant enzyme to metabolize dopamine [50-52], which is taken up by astrocytes via sodium-dependent and independent mechanisms [53-55]. The products of MAO-B mediated metabolism of dopamine are 3,4-dihydroxyphenyl-acetaldehyde, an ammonium molecule and $\mathrm{H}_{2} \mathrm{O}_{2}$. Hydrogen peroxide is highly membrane permeable entering into neighboring dopaminergic neurons where it can react with $\mathrm{Fe}^{2+}$ to form hydroxyl radical $[56,57]$. In support of the role of elevated MAO-B expression in neurodegeneration, inducing this enzyme in the astrocytes of adult transgenic mice results in selective and progressive loss of nigral dopaminergic neurons [58].

The products of dopamine oxidation, dopamine quinones, can also contribute to neurodegeneration [59]. Dopamine quinones can cyclize to form aminochrome, which is highly reactive and leads to the generation of superoxide and depletion of cellular NADPH. Aminochrome can form adducts with proteins such as alpha-synuclein [60] and is the precursor of neuromelanin, a brain pigment that may contribute to neurodegeneration by triggering neuroinflammation [61]. Postmortem brain analysis has shown significant increase in cysteinyl adducts of dopamine in PD substantia nigra suggesting accelerated oxidation, although this finding maybe related to L-dopa therapy [62].

The transport and storage of dopamine can also contribute to increased ROS production and cellular dysfunction. Normally, dopamine is sequestered in storage vesicles through an active transport process that requires vesicular monoamine transporter 2 (VMAT2) in preparation for the release of the transmitter after depolarization. Thus, VMAT2 keeps cytoplasmic dopamine levels under control preventing ROS generation. As a result, over-expression of VMAT2 confers protection against MPTP toxicity, while dopaminergic neurons with genetic or pharmacological blockade of VMAT2 are more susceptible to toxic insults [63]. In addition, the reuptake of synaptically released dopamine into nigrostriatal terminals requires dopamine transporters (DAT). Perturbations in this step again impact the levels of cytoplasmic free dopamine that is susceptible to be oxidized [64, 65]. As discussed further below, some gene products linked to inherited forms of PD are associated with enhanced dopamine reuptake and impaired storage suggesting that such mechanisms can contribute to the vulnerability of nigral neurons to oxidative stress.

\section{Neuromelanin}

Neuromelanin is a polymer pigment synthesized in catecholaminergic neurons in the brain that contains catecholamine-based compounds such as oxidized dopamine, dopamine metabolites as well as proteins and lipids [66, 67]. Although its biological role is not completely understood, several hypotheses have been proposed trying to elucidate its significance to PD. One of these hypotheses suggests that neuromelanin increases cellular vulnerability, purporting a correlation between the proportion of this pigment in different brain regions and neuronal loss $[68,69]$. However, this hypothesis cannot be supported since the amount of neuromelanin within individual dopaminergic neurons in the SNpc is similar to that in the ventral tegmental area (VTA), which is relatively resistant to neuronal loss in PD [70-72]. An alternative hypothesis has 
been proposed based on changes in the pigment itself rather than the amount, including increased density, modifications in its structure and decreased lipid content $[70,73]$. Neuromelanin may also play a role in PD through its interaction with metals since it is an intracellular store for iron [74]. Analysis of neuromelanin in the SN of PD patients has shown an early accumulation and overload of iron, which can potentially result in increased oxidative stress [75-77]. The interaction of neuromelanin with alpha-synuclein has also been suggested as a mechanism for this pigment to modulate neuronal vulnerability. alpha-Synuclein is over-expressed in individual melanized neurons [78-80], and its aggregates redistribute to neuromelanin in the SN early in PD but not in healthy controls [70]. Finally, neuromelanin that leaks from degenerating neurons may contribute to the neurodegenerative process by activating microglia [81].

\section{Glutathione}

Analysis of postmortem brain tissue from PD patients shows decreased amount of glutathione (GSH) relative to glutathione disulfide (GSSG) (GSH:GSSG ratio) in the SN compared to controls [82-86]. GSH is a tripeptide consisting of glutamate, cysteine and glycine, with the reactive thiol group of its cysteine residue serving as an effective antioxidant. GSH is synthesized in the cytoplasm but has to be transported to the mitochondria, where it functions as an antioxidant molecule [87, 88]. As oxidative stress induces apoptosis, the mitochondrial status of GSH has become recognized as an important marker in this event. There are also consistent observations that impaired complex I activity leads to increased ROS production and subsequent decrease in GSH levels. This decrease in GSH levels can result from decreased synthesis due to inhibition of glutathione reductase, or from increased levels of glutathione disulfide (GSSG) and altered GSH:GSSG ratio [89]. Conversely, depletion of GSH in the SN results in selective decrease of mitochondrial complex I activity likely via thiol oxidation of critical residues leading to marked reduction in overall mitochondrial function [90-93].

GSH levels are finely regulated in healthy neurons, and alterations from the physiological basal levels can induce cell death. Down-regulation of GSH synthesis in the rat brain has been shown to result in progressive degeneration of nigral dopaminergic neurons. Curiously, over-production of GSH in this model was also associated with cell death [94]. The mechanism of the latter finding remains unclear. In addition, diminished GSH content in SH-SY5Y cells results in inactivation of glutaredoxin 1 (Grx) and exacerbates the sensitivity of cells to L-DOPA-induced apoptosis [95]. Grx1 is involved in glutathionylation, a process characterized by the reversible formation of mixed disulfides between protein thiols and GSH [96]. Under conditions of moderate oxidative stress, proteins can be S-glutathionylated, and this process may protect the cell by preventing the irreversible oxidation of cysteine to cysteine sulfinic and sulfonic acid [97]. In fact, knock-down of Grx in SH-SY5Y cells results in increased apoptosis, supporting the notion that disrupting the regulation of protein glutathionylation may sensitize dopaminergic neurons to apoptosis [95, 98]. Additionally, consistent with the hypothesis of altered thiol-disulfide homeostasis in stressed dopaminergic neurons, mouse brains lesioned with MPTP exhibit decreased activity of isocitrate dehydrogenease (IDH) [97]. This enzyme catalyzes the oxidative decarboxylation of isocitrate to alpha-ketoglutarate, which requires either $\mathrm{NAD}^{+}$or $\mathrm{NADP}^{+}$with the consequent production of NADH and NADPH, respectively. NADPH is an essential reducing equivalent for the regeneration of GSH by glutathione reductase and for the activity of the NADPH-dependent thioredoxin system, both playing important roles in protecting cells from oxidative damage $[99,100]$. Thus, IDH contributes to the supply of NADPH needed for GSH production against oxidative damage [101], and the activity of IDH can be important for the regulation of cell survival. Therefore, oxidantinduced deactivation of this enzyme can play a role in PD [43].

Iron

Postmortem brain tissue from PD patients has higher levels of iron in the SN compared to controls [102-105]. The possible association of oxidative/nitrosative iron dysregulation in the neurodegenerative process of $\mathrm{PD}$ is also supported by the presence of nitrosylated iron regulated protein 2 (IRP) in Lewy bodies in the SN $[106,107]$. Iron is an important element for almost all cell types, including brain cells. It is an essential cofactor for proteins involved in the normal function of neuronal tissues, such as the non-heme iron enzyme TH required for the synthesis of catecholamine neurotransmitters [108]. Iron ions can generate ROS since ferric iron $\left(\mathrm{Fe}^{3+}\right)$ and ferrous iron $\left(\mathrm{Fe}^{2+}\right)$ can react with superoxide and hydrogen peroxide, respectively, in a chain reaction generating the highly reactive hydroxyl free radical, 
which together with dopamine oxidation can trigger neurotoxicity [109, 110].

In normal brains, iron displays a heterogenous pattern of regional distribution with greater abundance in the globus pallidus, putamen and $\mathrm{SN}$ of the basal ganglia [111]. However, with aging and degenerative processes such as PD, there is an abnormal, progressive deposition of iron and increased free iron concentration in the SNpc [102]. Although several studies confirm this increase, the stage of the disease at which iron changes occur is controversial. One aspect of the debate is whether elevated iron levels represent a cause or the result of neuronal destruction $[102,110]$. In the early presymptomatic stage of $\mathrm{PD}$, no significant increase in iron content in the SN is detected, as opposed to symptomatic PD patients. This supports the notion that elevation of iron content may be a secondary event in the neuronal degeneration. An alternative explanation is that elevated iron content in symptomatic disease may accelerate and worsen the neuronal degeneration via oxidative stressmediated pathways [112]. On the other hand, iron levels can be enhanced by oxidative stress through several pathways including increased release of iron from ferritin by superoxide anion, from heme proteins such as hemoglobin and cytochrome $\mathrm{c}$ by peroxidase, and from iron-sulfur proteins by peroxynitrite [91, 113, 114]. Experimentally, iron accumulation can occur as an early event in dopaminergic neuronal loss since exposure of neonatal mice to iron results in Parkinson-like neurodegeneration with age. These animals exhibit striatal dopamine depletion by 12 months of age, develop progressive nigral neuronal loss by 24 months of age, and become more vulnerable to toxic injury [115]. Additionally, feeding a high iron diet to one month old weanling mice or stereotaxic infusion of iron into the SNpc of rats results in significant increase in iron levels in the striatum, associated with decreased levels of total glutathione (GSH and GSSG) and increased levels of hyroxyl radical [116]. On the other hand, intramuscular injection of the iron chelator desferrioxamine significantly lowers iron levels in the brain and has a neuroprotective effect against iron and MPTP in mice [117]. These results collectively suggest that increases in midbrain iron levels can be a contributor to the neurodegeneration associated with PD [116, 117].

\section{Calcium}

The regulation of intracellular $\mathrm{Ca}^{2+}$ is a metabolically expensive process that requires the actions of
ATP-dependent pumps [118] and, therefore, results in increased mitochondrial activity and concomitant increased ROS generation. Studies with primary mesencephalic dopaminergic neurons in culture have shown that the opening of L-type $\mathrm{Ca}^{2+}$ channels leads to increased mitochondrial oxidant stress in dendrites [119]. In addition, the formation of alpha-synuclein aggregates exacerbates this effect in perinuclear and dendritic compartments [119].

Differences in the regulation of $\mathrm{Ca}^{2+}$ homeostasis may explain the greater susceptibility of dopaminergic neurons in the SNpc compared with their counterparts in other brain regions. In contrast to nigral neurons, VTA dopaminergic neurons, which are relatively spared in PD [71, 72], have much lower density of the L-type calcium channel $\mathrm{Ca}_{\mathrm{v}} 1.3$ [120], do not manifest $\mathrm{Ca}^{2+}$ oscillations, and express high levels of the $\mathrm{Ca}^{2+}$-buffering protein calbindin [71]. Instead VTA neurons use $\mathrm{HCN} / \mathrm{Na}^{+}$channels for pacemaking. Thus, cytoplasmic dopamine levels are higher in SN neurons than in VTA dopaminergic neurons [121]. These findings suggest that the differences in calcium signaling could contribute to increased susceptibility of SN neurons and consequently cell death [121].

\section{Lipids}

The brain has high concentrations of polyunsaturated fatty acids, such as docosahexaenoic acid and arachidonic acid, compared with other organs. As these fatty acids are highly unsaturated, oxidative stress makes them susceptible to lipid peroxidation, which is one of the major outcomes of free radical-mediated injury [122]. Lipid peroxidation results in structural damage of membranes, compromising their integrity and consequently cell viability. As some of the lipid peroxidation products are chemically reactive, they are believed to be the major effectors of tissue damage [123]. In fact, lipid peroxidation can perpetuate in the presence of free reactive iron, since iron can react with lipid hydroperoxides to generate alkoxyl radical, which in turn can react with polyunsaturated fatty acids, the substrate for lipid peroxidation [124].

4-Hydroxyl-2-nonenal (HNE) is a highly reactive lipophilic alpha, beta-alkenal, which can form stable adducts with thiol or amine groups on proteins. HNE can also activate members of the caspase family and cause DNA fragmentation, leading to apoptosis [125]. Additionally, HNE decreases GSH levels due to its rapid consumption via GSH peroxidase and the high reactivity of HNE with sulfhydryl groups [126]. 
Thus, the high propensity of polyunsaturated fatty acids for peroxidation under oxidative stress conditions can result in neuronal damage and contribute to PD progression. In support of this possibility, levels of lipid peroxidation products including HNE and malondialdehyde are increased in the SN of PD patients, while polyunsaturated fatty acids are decreased [124]. Elevated HNE levels are also detected in the cerebrospinal fluid of these patients [9, 127].

\section{MITOCHONDRIAL DYSFUNCTION}

Although substantial evidence points to the presence of oxidative stress in PD, it is not entirely clear whether accumulation of ROS is a primary event or a consequence of other cellular dysfunctions. Since mitochondria play a dual function as source and target of ROS, compelling evidence suggests that mitochondrial dysregulation plays a critical role in the pathogenesis of PD. Mitochondria are dynamic organelles with many functions. Besides their role in energy generation, they are closely involved in calcium homeostasis, stress response and cell death pathways. Therefore, impairment of mitochondrial function leads to cellular damage and is related to neurodegeneration [4].

The electron transport chain is the major source of ROS, since during reduction of oxygen to water a small percentage of superoxide anion is produced [128-130]. The process of electron transfer creates a proton gradient across the inner mitochondrial membrane that drives the synthesis of ATP through ATP synthase (complex V). Complexes I, II, III and some dehydrogenases of the tricarboxylic acid (TCA) cycle may also generate superoxide anion $[128,131]$. In turn, manganese superoxide dismutase (MnSOD) can convert superoxide to $\mathrm{H}_{2} \mathrm{O}_{2}[132,133]$.

Complex I (NADH:ubiquinone oxidoreductase) catalyses the first step in the mitochondrial electron transport chain. It extracts energy from the oxidation of NADH and transfers it to ubiquinone, generating ubiquinol. Ubiquinol is a membrane-soluble carrier that releases a pair of electrons to Complex III [134]. Complex II (succinate-coenzyme Q reductase) makes the link between the TCA cycle and the electron transport chain, releasing electrons to Complex III through ubiquinol [135]. Complex III (ubiquinone-cytochrome c oxidase) contributes to the proton gradient through the reduction of cytochrome c by oxidation of ubisemiquinone and the pumping of protons from the mitochondrial matrix into the inter- membrane space [136]. When there is a decrease in electron transfer, molecular oxygen can capture electrons from Complex III, resulting in superoxide anion formation [128, 137, 138].

Mitochondrial dysfunction was first linked to PD upon the recognition of MPTP-induced parkinsonism among some drug abusers, and the finding of significant dopaminergic neuron loss in their SN at post-mortem analysis [139]. MPTP crosses the bloodbrain barrier and is taken up by astrocytes where it is metabolized into 1-methyl-4-phenylpyridinuim $\left(\mathrm{MPP}^{+}\right)$by MAO-B and released into the extracellular space. $\mathrm{MPP}^{+}$is a substrate for the dopamine transporter and is taken up selectively into dopaminergic neurons where it inhibits Complex I of the mitochondrial electron transport chain [15]. Several groups have reported decreased Complex I activity and ubiquinone in the SN of PD patients, abnormalities that may lead to neuronal degeneration [140-142]. In addition, gene expression profiling in dopaminergic neurons from PD patients showed down-regulation of genes encoding mitochondrial proteins, among others, providing further evidence for mitochondrial dysfunction in PD [143]. Unexpectedly, complex I deficiency has also been observed in the platelets and skeletal muscle of PD patients [144-146], although not all reports agree about the latter likely due to methodological differences [147, 148]. Nevertheless, it seems clear that mitochondrial function is impaired in PD at different levels ranging from organelle biogenesis, mitochondrial fusion/fission, to mitophagy. Additionally, some of the inherited PD-linked proteins play a significant impact in this process [3, 5, 7, 149-154]. For example loss of ATP13A2, a P-type ATPase associated with an autosomal recessive atypical parkinsonian syndrome is associated with increased mitochondrial mass resulting in increased oxygen consumption and increased ROS production in cultured cells [155]. More about the role of mitochondria in PD pathogenesis is reviewed below under PD-linked proteins.

\section{UBIQUITIN-PROTEASOME SYSTEM (UPS)}

The ubiquitin-proteasome system (UPS) is the main pathway through which cells degrade and remove damaged and unwanted proteins [156]. During oxidative stress, the efficient clearance of these unwanted materials by the proteasome is considered as a defense mechanism, since degradation lessens the threat of oxidized proteins forming toxic aggregates. In addition, the amino acid products released in the process of 
degradation, which may become oxidized and thereby function as ROS scavengers, can protect vital cellular components from oxidation [157-159]. Mutations in the genes for parkin and ubiquitin carboxy-terminal hydrolase L1 (UCH-L1), which are linked to PD and are components of the UPS, indicate a role for UPS in PD pathogenesis [156]. UPS is also involved in the degradation of defective mitochondria, thus, minimizing the production of oxidative free radicals $[160$, 161]. Additionally, alpha-synuclein, the key component of Lewy bodies, is a substrate of the UPS [161], while oxidatively damaged and aggregated alphasynuclein impairs proteasomal function [162, 163]. Inhibition of mitochondrial Complex I also impairs proteasomal activity through oxidative modification of proteasome components besides increasing the production of oxidatively damaged proteins [164]. In the SNpc of PD patients, evidence has been presented for impaired UPS with structural proteasome alterations including loss of the alpha-subunit, the component that regulates and stabilizes the proteasome complex $([165,166]$. In culture, cell death induced by proteasome inhibitors leads to a cascade of events involving increased oxidative and nitrosative stress, as well as damage to and alterations of mitochondrial function [167]. Thus, increased oxidative stress can cause UPS dysfunction, which in turn exacerbates the vulnerability of nigral dopaminergic neurons in PD [168].

\section{NEUROINFLAMMATION}

Several lines of evidence support a role for neuroinflammation in the pathophysiology of PD mediated mainly by activated microglia [169]. Microglia are phagocytic cells, components of the innate immune system of the central nervous system, that usually have a resting phenotype but become activated upon brain injury or immune challenge [169]. Activated microglia are an important source of superoxide and nitric oxide, which in turn contribute to oxidative and nitrative stress in the brain microenvironment. They can also promote neurodegeneration by producing other potentially toxic agents such as glutamate and tumor necrosis factor-alpha [44, 169-171]. In addition, astrogliosis within the SN leads to local microglia activation [58]. But microglia also have a dual role in the brain, acting as neuroprotective cells through the elimination of endogenous or exogenous substances, and they have high levels of GSH and glutathione peroxidase, which act to protect them from toxic levels of $\mathrm{H}_{2} \mathrm{O}_{2}$ [172].
Notably, activated microglia and T lymphocytes have been detected in the SN of patients with PD along with an increase of pro-inflammatory mediators in the brain and cerebrospinal fluid [29, 173-175]. Postmortem studies have also revealed the presence of inducible NO synthase (iNOS) in activated microglia of PD nigra [29]. Moreover, microglial activation is observed in in vitro and in vivo models using toxins such as MPTP, rotenone or 6-OHDA, as well as with lipopolysaccharide (LPS) [176-180]. Dopaminergic neuronal death releases oxidized proteins, lipids and DNA in the extracellular space that are recognized as damaged molecules by microglia causing their activation. Microglial activation in turn leads to increased cytokine formation, increased production of reactive oxygen and nitrogen species, and decreased secretion of trophic factors responsible for the normal maintenance of neuronal viability [176-180]. Thus, neuronal death aggravated by microglia further induces the activation of microglial cells, creating a neurotoxic vicious cycle [169]. Since the midbrain contains more microglial cells compared to other brain regions, these cells would be particularly damaging to dopaminergic neurons [181].

Although microglia activation and inflammatory changes are generally considered as a consequence of neuronal destruction, the finding of human leukocyte antigen (HLA) as a risk factor for PD in Genome-Wide Association Studies (GWAS) raises the possibility for a more general pro-inflammatory state in this disease as a primary cause of neuronal loss in some cases or at least increasing PD risk as a disease modifier genotype [182, 183]. Interestingly, even peripheral inflammation, for example induced by the injection of carrageenan into the rat paw, reportedly exacerbates LPS-induced inflammatory changes in the SN along with greater dopaminergic neuron loss [183]. Several studies have suggested a link between the innate inflammatory response of the central nervous system and the peripheral immune system [184]. Increased concentration of neuroinflammatory markers, such as IL-2, IL-6, TNF-alpha, osterpontin and RANTES/chemokine (C-C motif) ligand 5 has even been detected in the serum of PD patients [184], but these findings need to be validated. Nevertheless, these preliminary results raise the hypothesis that the loss of dopaminergic neurons induced by a genetic insult or environmental toxin can be exacerbated by a mild to moderate peripheral inflammation [185]. All these observations suggest that neuroinflammation along with its consequences including oxidative stress is a critical component of the pathogenesis of PD. 


\section{PHYSIOLOGICAL AND EXTERNAL DETERMINANTS OF OXIDATIVE STRESS IN PD}

Besides genetic determinants that exacerbate oxidative stress described below [186], other factors that play a role in the redox status of an organism are recognized as risk factors for the development of PD. These include aging and environmental factors such as exposure to toxins.

\section{Aging}

Age is the main risk factor for PD, with an exponential increase of the disease occurrence above the age of 65 [187-189]. Besides the presumed decades needed for misfolding of pathogenic proteins to reach a critical threshold to incur neuronal damage, age associated impairment of mitochondrial function and consequent increased ROS production appear to be important aspects in neurodegenerative disorders that develop later in life [186, 189-191]. In aged and PD afflicted brains, high levels of mitochondrial DNA (mtDNA) deletions are found in pigmented neurons of the substantia nigra [192-195], and ROS-mediated damage can result in mutations in the mitochondrial genome [196-198]. This leads to the expression of mutant forms of the electron transport chain subunits and mitochondrial transfer RNAs essential for translation [199], collectively exacerbating ROS production. This scenario would create a vicious cycle of further injury to mtDNA and other mitochondrial components, thus, increasing ROS production [192-194, 200]. Additionally with aging, mitochondrial function diminishes concomitant with changes in their morphology and decreased number [201], and age-related decreased autophagy results in the accumulation of defective mitochondria [202, 203].

\section{Toxins}

Epidemiologic studies corroborate an association between exposure to pesticides frequently used in agriculture with the increased risk of developing PD [204-207]. Sera from PD patients have higher levels of these substances than controls [204, 205], and organochlorine insecticides are detected at higher levels in the PD substantia nigra than in non-PD brains [208]. The risk may be increased after exposure to multiple pesticides compared to exposure to any one alone [209, 210]. In addition, consumption of pesticidecontaminated well-water may increase the risk of PD
[211]. Although these toxins act through different mechanisms, they share a common feature of increased oxidative stress due to increased ROS production. For example, the herbicide paraquat, which is linked to increased risk of PD [210, 212-215], undergoes redox cycling and is reduced by NADPH before being oxidized by an electron acceptor to produce superoxide [216]. The pesticide rotenone can freely cross cellular membranes and accumulates in mitochondria, where it inhibits Complex I by impairing oxidative phosphorylation [16]. The results of these epidemiologic studies support a contribution of oxidative stress to the pathogenesis of dopamine neuronal loss in PD.

\section{THE ROLE OF PD-RELATED PROTEINS IN OXIDATIVE STRESS}

The discovery of genes linked to familial forms of PD, such as alpha-synuclein, parkin, DJ-1, PINK1 and Leucine-rich repeat kinase 2 (LRRK2) has yielded important insights into the molecular pathways in the disease pathogenesis and highlighted previously unknown mechanisms by which oxidative stress contributes to the disease (Fig. 1). Some of these mechanisms are complex, involve various cell biologic processes, and are modulated by several of these proteins. These discoveries are also beginning to help interpret some of the biochemical defects in the PD brain.

\section{alpha-Synuclein}

alpha-Synuclein is a natively unfolded protein that can associate with vesicular and membranous structures and plays a role in synaptic vesicle recycling, storage and compartmentalization of neurotransmitters [217-219]. Mutations and multiplication of the SNCA gene are linked to dominantly inherited PD and increase the propensity of the protein to aggregate [220-224]. Fibrils of alpha-synuclein are present in Lewy bodies [225], and the formation of aggregates is associated with increased oxidative or nitrosative stress [107, 226, 227]. Oxidative conjugation of dopamine with alpha-synuclein inhibits the transition of alphasynuclein from protofibrils to mature fibrils, leading to the potential accumulation of cytotoxic soluble protofibrils in dopaminergic neurons. The addition of antioxidants has the ability to reverse the formation of these adducts, suggesting that catechol oxidation can contribute to the accumulation of alpha-synuclein protofibrils [91, 228]. 


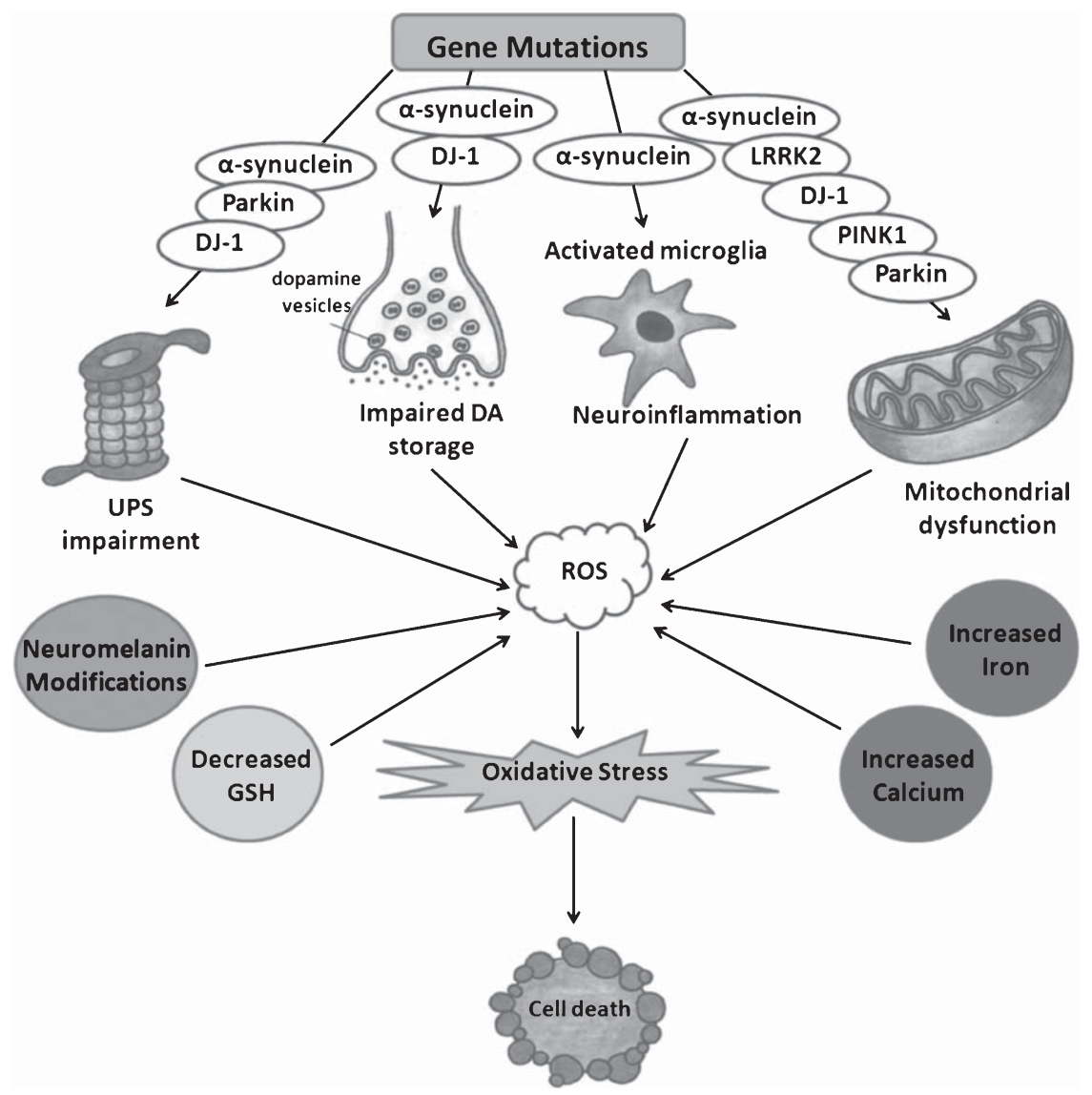

Fig. 1. Mechanisms leading to oxidative stress in PD and the role of PD-related gene products in this process. DA = dopamine; ROS $=$ reactive oxygen species; UPS = ubiquitin-proteasome system; GSH = glutathione.

Additional in vitro and in vivo experiments support the notion that increased oxidative stress in the brain may contribute to alpha-synuclein aggregation [226]. For example, incubation of recombinant alphasynuclein with cytochrome $\mathrm{c}$ in the presence of $\mathrm{H}_{2} \mathrm{O}_{2}$ [162], or exposure of cells in culture to $\mathrm{H}_{2} \mathrm{O}_{2}$ and ferrous iron, $\mathrm{MPP}^{+}, \mathrm{NO}$ and superoxide promotes alpha-synuclein aggregation [226, 229, 230]. Additionally, oxidative stress can cause nuclear membrane modifications and alpha-synuclein translocation to the nucleus where it can form complexes with histones leading to its oligomerization into insoluble fibrils [231-233]. In vivo studies with rats also demonstrated alpha-synuclein aggregation following systemic exposure to the pesticides rotenone [234] or dichlorvos [235]. Additionally, alpha-synuclein transgenic mice exposed to paraquat exhibit increased proteinase-Kresistant alpha-synuclein inclusions [236].

Besides the impact of oxidative stress in promoting alpha-synuclein aggregation, the over-expression or misfolding of alpha-synuclein, and particularly its mutant variants, is associated with increased ROS production [237, 238]. As a result, experiments with cultured cells have demonstrated that over-expression of wild-type or mutant alpha-synuclein increases sensitivity to dopamine toxicity [237, 239, 240]. Similar observations have been made in vivo whereby mice over-expressing mutant or wild-type alphasynuclein exhibit increased sensitivity to MPTP and 6-OHDA [241-243]. Conversely, mice lacking alphasynuclein demonstrate marked resistance to MPTP and other mitochondrial toxins such as malonate and 3nitropropionic acid [244, 245]. Notwithstanding the shortcomings of over-expression studies, these results suggest that ROS promotes alpha-synuclein aggregation, which in turn increases ROS, creating a vicious cycle leading to neurodegeneration.

Several mechanisms have been proposed to explain the increased oxidative stress in the brain in the context of alpha-synuclein misfolding. One possible mechanism can be increased cytosolic catecholamine concentrations, which result from the disruption of 
vesicular membrane integrity by pore forming alphasynuclein protofibrils [246], thus, exacerbating the toxicity of oxidized catechol metabolites [247, 248]. alpha-Synuclein may also play a role in synaptic vesicle recycling through its interaction with phospholipase D2 (PLD2) localized primarily in the plasma membrane [249]. Misfolded or mutated alphasynuclein has been suggested to result in dysregulated vesicle recycling through PLD2 related mechanisms, leading to reduced number of vesicles available for dopamine storage [250]. In addition to alpha-synuclein disrupting vesicular membrane integrity and recycling, it can also interact with dopamine transporter on the plasma membrane causing clustering of the transporter and greater reuptake of this neurotransmitter into the neuron [251]. These processes that can lead to increased cytosolic dopamine concentrations by alphasynuclein are implicated in the relative susceptibility of dopaminergic neurons in PD [247, 248].

alpha-Synuclein can also bind to the inner mitochondrial membrane where it associates with complex I, decreasing its activity, and impairing mitochondrial function [238, 252-259]. This interaction is supported by in vivo studies demonstrating alpha-synuclein in the mitochondrial membrane of dopaminergic neurons of the mouse brain [254], and in the mitochondrial fraction of human dopaminergic neurons, whereby levels in the SN and striatum are higher in postmortem PD brains than control subjects [258]. In neuroblastoma cell lines, iron overload leads to the aggregation of alpha-synuclein with clumped mitochondria [231]. Functional studies have shown that the binding of alpha-synuclein to mitochondria is followed by cytochrome c release, increased calcium and ROS levels resulting in cell death [260]. The release of cytochrome $\mathrm{c}$ has been suggested to be the primary event that leads to apoptotic cell death in alpha-synuclein induced oxidative stress [261]. alpha-Synuclein can also increase mitophagy, which is an important cellular homeostatic process to remove aged and dysfunctional mitochondria and protect cells against high levels of ROS. However, it is also hypothesized that excessive mitophagy may remove functional mitochondria resulting in bioenergetic failure [262]. Structural and functional abnormalities of mitochondria have been observed with the overexpression of mutant or wild-type alpha-synuclein and have been associated with oxidative stress [263, 264]. Additionally, alpha-synuclein can impact mitochondria indirectly. Under conditions of oxidative stress, it localizes to the nucleus and binds to the promoter of peroxisome proliferator-activated recep- tor gamma-coactivator-1 alpha (PGC1 $\alpha)$ gene leading to down-regulation of PGC1 $\alpha$-target genes and consequently disturbing mitochondrial morphology and function [265].

The neurotoxicity of alpha-synuclein can also be mediated by the activation of microglia leading to increased ROS generation [252, 266-269]. Microglial BV-2 cell line incubated with conditioned media from SH-SY5Y cells over-expressing wild-type or mutant alpha-synuclein release proinflammatory cytokines such as TNF-alpha and IL1-alpha [270, 271]. Similarly, exposure of primary microglial cells to recombinant aggregated or mutated alphasynuclein results in increased activated microglia and ROS production followed by the secretion of TNF-alpha, IL6 and IL-1beta [266, 272, 273] and the activation of intracellular pathways such as ERK1/2 and p38 MAPK [272]. Neuron/glia coculture experiments have also shown exacerbation of dopaminergic neuronal toxicity that is made worse with increasing percentage of microglial cells in the plate [274-276]. Mutant alpha-synuclein produces greater insult in this regard than wild-type protein [274]. alpha-Synuclein also promotes microglia activation and ROS production induced by LPS treatment [276]. Similar results have been observed in in vivo models, where mice over-expressing wild-type alphasynuclein exhibit a neuroinflammatory response with microglial and astrocytic activation and neurotoxicity [266, 277-280]. One proposed mechanism for alphasynuclein induced microglial activation is through the release of misfolded alpha-synuclein from dying dopaminergic neurons into the nigral parenchyma. In this regard, evidence has been presented for oligomeric alpha-synuclein as an agonist for tolllike receptor 2 (TLR2) and the importance of this signaling pathway in microglia activation [281]. Additionally, alpha-synuclein induced microglial activation is partially attenuated with microglia from mice lacking the scavenger receptor CD36, suggesting a role for this pattern recognition receptor in this process [266]. Further, microglial activation appears to require alpha-synuclein phagocytosis and NADPH oxidase activation, since knocking down this enzyme results in attenuated ROS release from microglia and protects dopaminergic neurons in primary mesencephalic neuron-glia co-cultures when challenged with alphasynuclein [276].

The ability of alpha-synucleiln to activate microglia is exacerbated when it is nitrated, a process that increases its propensity to aggregate and become resistant to proteolysis [273, 276, 282]. Besides the 
potential role of nitrated alpha-synuclein in the activation of the brain's innate inflammatory response, this protein can also activate the adaptive immune response with increased leukocyte infiltration [244, 279, 283]. The more persistent neuroinflammatory response seen in transgenic mice carrying the human alpha-synuclein A53T mutation following systemic LPS administration compared with wild-type mice is associated with the accumulation of nitrated alphasynuclein and dopamine neuron degeneration [284].

Iron is among the factors that accelerate the propensity of alpha-synuclein to aggregate [162, 261, 285-288]. In addition, the two have a synergistic action in neurotoxicity through the nuclear factor erythroid 2-related factor (Nrf2) and heme oxygenase-1 (HO-1) pathway. In SK-N-SH neuroblastoma cells, ferrous iron down-regulates Nrf2 and HO-1, and this effect is exaggerated when alpha-synuclein is overexpressed, resulting in increased cell toxicity. On the other hand, knocking down alpha-synuclein prevents down-regulation of Nrf2 and HO-1 induced by ferrous iron and protects cells against ferrous iron-induced cell death [289]. The presence of a putative iron-responsive element (IRE) in the 5'-UTR of the alpha-synuclein mRNA raises the possibility of iron-dependent translational control of expression as well. This is based on the similarity between the sequences present in the alpha-synuclein mRNA and the IRE present in the ferritin 5'-UTR. Accordingly, HEK293 cells treated with the iron chelator desferrioxamine have decreased alpha-synuclein mRNA levels [290]. Therefore, iron may regulate alpha-synuclein levels and aggregation via the IRE/ iron regulatory protein system (IRP) and may impact oxidative stress through this pathway as well.

Maintaining physiologic levels of alpha-synuclein in neurons is important for their survival. Chaperonemediated autophagy (CMA) clears aggregated alphasynuclein and prevents its accumulation. However, post-translational modifications of alpha-synuclein impair its degradation by CMA. Studies with cultured cells and isolated lysosomes have shown that dopamine-modified alpha-synuclein is not only poorly degraded by CMA but also blocks the degradation of other substrates that utilize this pathway, thus, causing considerable cellular stress [291].

A critical process that leads to the progressive neuropathology in PD is the prion-like trans-neuronal propagation of alpha-synuclein [292, 293]. The endocytosis of alpha-synuclein into neurons triggers abnormal protein aggregation leading to a cytotoxic cascade that culminates in mitochondrial dysfunction and cell death demonstrated in primary human fetal enteric neurons [294]. Notably, HNE induces alphasynuclein oligomerization, enhances its translocation to vesicles and its release from cells, and hence promotes alpha-synuclein oligomers to be transferred across cells [295].

The dual pathogenetic mechanisms whereby the biology of alpha-synuclein is altered by oxidative stress while oxidized or nitrated alpha-synuclein has greater neurotoxicity create a feed forward state of progressive neuronal death seen in PD.

\section{Parkin}

Parkin is a cytoplasmic and nuclear protein that functions as an E3 ubiquitin ligase, and the loss of this activity due to mutations is associated with autosomal recessive early-onset PD [296-298]. Parkin plays a role in neuroprotection against several insults, including alpha-synuclein toxicity and oxidative stress, and it is crucial for dopamine neuron survival [299].

Several reports have provided a link between parkin and oxidative stress. SH-SY5Y cells overexpressing wild-type parkin have decreased ROS levels and are relatively protected against apoptosis induced by dopamine or 6-OHDA [300]. On the other hand, expression of mutant parkin is associated with increased levels of protein carbonyls, lipid peroxidation and nitrated proteins [301]. One possible way for parkin to exert neuroprotection against oxidative stress is via its role in the clearance of damaged mitochondria, which would generate ROS. Under physiologic conditions, the majority of parkin is localized in the cytosol, but upon oxidative stress it translocates to depolarized mitochondria, inducing their autophagic elimination [154, 302]. In this process, parkin ubiquitinates multiple mitochondrial substrates, including proteins involved in mitochondrial fusion [303, 304], leading to their degradation by the UPS and mitophagy [305]. Drosophila expressing mutant Parkin exhibit age-dependent degeneration of dorsomedial dopaminergic neurons with aberrant morphology [306-308]. These flies also have swollen mitochondria with disruption and disintegration of the cristae, which are associated with muscle dysfunction [307]. And in mice, alpha-synuclein mediated mitochondrial dysfunction is further exacerbated in parkin knockout background [309].

The E3 ligase activity of parkin is impaired by posttranslational modifications induced by oxidative or nitrosative stress [310, 311]. For example, in dopaminergic neuronal MES23.5 cells stably expressing human 
parkin, dopamine treatment modifies parkin, decreasing its solubility and inactivating its E3 ubiquitin ligase function [310]. In addition, S-nitosylated parkin has been detected in HEK 293 cells transfected with parkin and treated with the NO source S-nitrosoglutathione [310]. Moreover, in the brains of PD patients, evidence has been presented for the presence of nitrosylated parkin, which had poor solubility [311]. These observations suggest that parkin can indirectly regulate the oxidant stress level of cells through regulating the UPS and contributing to mitochondrial quality control, and that its activity can also be impacted by such stress.

\section{PINK1}

PTEN-induced putative kinase 1 (PINK1) is a mitochondrially targeted serine-threonine kinase, whose mutations are linked to autosomal recessively inherited PD [312-314]. PINK1 mutations are associated with loss of its kinase function [152] and, thus, its enzymatic activity appears to play an important role in neuroprotection. Accumulating evidence suggests PINK1 as a key regulator of mitochondrial quality control, supporting preservation of mitochondrial respiration through cristae stabilization, phosphorylation of chaperones and possibly regulation of mitochondrial transport or mitophagy [312-315].

Mitochondria are recognized as the main target organelle for normal PINK1 function. PINK1 deficiency results in shortening, swelling and fragmentation of mitochondria in cultured cells [150, 316-319] associated with loss of mitochondrial enzyme activity, particularly that of Complex I [151, 320-323]. In addition, knocking down PINK1 in SH-SY5Y cells results in decreased mitochondrial DNA synthesis followed by loss of mitochondrial membrane potential and decreased ATP production [320]. On the other hand, over-expressing wild-type PINK1 in neuronal cell lines protects against staurosporine-induced mitochondrial cytochrome c release and subsequent apoptosis through caspase 3 activation, while PINK1 mutants lack this protective effect [314] and enhance oxidative stress-induced cell death [324]. Further, induced pluripotent stem cells (iPSC) from PINK1 mutant human subjects have increased vulnerability to $\mathrm{MPP}^{+}$ and hydrogen peroxide [325].

The impact of PINK1 deletion on mitochondria is also demonstrated in vivo. Mice lacking the PINK1 gene exhibit an increase in the number of larger mitochondria in the striatum with no change in total mitochondria numbers. These morphological changes are associated with impaired mitochondrial respiration in the striatum but not in cerebral cortex, suggesting specificity of this defect for the nigrostriatal dopaminergic circuitry. PINK1 knockout mice also show increased sensitivity to oxidative stress [151], since mitochondria isolated from the brains of these animals exhibit increased cellular stress induced by $\mathrm{H}_{2} \mathrm{O}_{2}$ compared with mitochondria isolated from wild-type mice [151]. Together, these results suggest that loss of PINK1 function results in mitochondrial dysfunction, increasing susceptibility to oxidative stress-induced cell death. Accordingly, measures that enhance the antioxidant potential of cells can mitigate the consequences of PINK1 deficiency. For example, Drosophila over-expressing human SOD1 or treated with vitamin $\mathrm{E}$ are protected from dopaminergic neuron loss induced by PINK1 inactivation [326]. Evidence for oxidative stress and compensatory changes has also been demonstrated in fibroblasts and lymphoblasts obtained from PD patients homozygous for a PINK1 mutation. These cells have increased lipid peroxidation as shown by increased malondialdehyde levels, slightly decreased Complex I activity and a trend to superoxide elevation. This profile is accompanied by compensatory induction of two antioxidant defenses, mitochondrial superoxide dismutase and the glutathione pathway with elevated levels of glutathione reductase and glutathione-S-transferase [327].

PINK1 can also modulate mitochondrial function and oxidative stress through its functional interactions with other PD linked proteins. The best studied interaction is the PINK1/parkin pathway. PINK-1 mutant flies share a similar phenotype as parkin mutants [152, 328], and over-expression of parkin can rescue the mitochondrial defects of PINK-1 mutant flies [152, 328, 329]. Parkin can also protect PINK1 deficient mice against MPTP [330]. Mechanistically, PINK1 and parkin work together for the selective clearance of damaged mitochondria through mitophagy [303]. When mitochondria are damaged, parkin translocates to mitochondria to initiate mitophagy. However, if PINK1 is knocked down by RNAi, both the translocation of parkin and mitophagy are abrogated indicating that PINK1 is required for the recruitment of parkin to damaged mitochondria [303, 331].

Besides its functional interaction with parkin, PINK1 can also act as a neuroprotective protein against oxidative stress through its interaction with DJ-1 [332]. Over-expression of DJ-1 and PINK1 synergistically protects SH-SY5Y cells against MPTP-induced cell death; this effect is lost in the presence of A39S mutant DJ-1 and P399L mutant PINK1 [332]. In vivo, 
viral vector mediated expression of DJ-1 mitigates the increased sensitivity of PINK1 deficient mice to MPTP [330]. Similarly, ubiquitous up-regulation of DJ-1 in Drosophila can ameliorate the phenotype of PINK1 deletion [333]. Another Drosophila model that used RNAi mediated down regulation of PINK1 and muscle specific expression of DJ-1 failed to demonstrate this rescue effect [329, 334]. Collectively, however, the available information suggests that DJ-1 acts either downstream of PINK1 or in a pathway that is parallel with the PINK1/parkin pathway [333, 335]. The precise mechanism of this synergy between DJ-1 and PINK1 in protecting cells and maintaining their homeostasis in an oxidative environment remains unclear.

\section{DJ-1}

DJ-1 is an evolutionarily conserved neuroprotective protein that regulates anti-oxidant, anti-apoptotic, and anti-inflammatory pathways [336]. It accomplishes these beneficial effects through several mechanisms including through acting as an ROS quencher, transcriptional co-activator and molecular chaperone [337-339]. It is expressed ubiquitiously in both neurons and glial cells [340]. Mutations in the DJ-1 gene are linked to autosomal recessive, early-onset PD [341].

The role of DJ-1 as a neuroprotective protein has been established in several models using toxins that mimic the oxidative stress in PD. A number of in vitro and in vivo studies have established that over-expression of wild-type DJ-1 is protective against $\mathrm{H}_{2} \mathrm{O}_{2}$, 6-OHDA, rotenone or MPTP, while DJ-1 mutants lack this effect [337, 342-347]. On the other hand, knocking down DJ-1 exacerbates the cell death induced by oxidative stress, as well as in response to other insults such as endoplasmic reticulum (ER) stress, proteasome inhibition and calcium entry [342, 348, 349]. Accordingly, transgenic mice expressing a redox-sensitive optical probe targeted to the mitochondrial matrix show, as a consequence of calcium influx, increased mitochondrial oxidative stress, which is exacerbated by knocking out DJ-1 [350]. As expected, DJ-1 knockout mice are more susceptible to MPTP and 6-OHDA than wild-type mice [344, 351, 352], although they do not exhibit dopamine neuronal degeneration at basal conditions [353-355]. Conversely, over-expression of DJ-1 in mice ameliorates MPTP-induced nigral neuronal loss [344, 351, 352]. Similarly, microinjection of DJ-1 protein into the medial forebrain bundle of the rat 6-OHDA model of PD dramatically improves the phenotype, including motor behavior, striatal dopamine and tyrosine hydroxylase content, and nigral neuronal count [356].

DJ-1 deficiency has also been modeled in Drosophila melanogaster and Caenorhabditis elegans. The fruit fly has two DJ-1 orthologs, DJ-1alpha and DJ1beta, with DJ-1alpha being predominantly expressed in the testis, and DJ-1beta ubiquitously expressed [333, 357-359]. Mutant flies with both homologs deleted display no loss of dopaminergic neurons at basal conditions but have increased sensitivity to oxidative stress induced by paraquat or rotenone [333, 357-359]. Double mutant flies also have defective mitochondrial respiration, ATP production and shortened lifespan [333]. DJ-1beta loss-of-function mutant flies exhibit increased number of enlarged mitochondria, which confers increased sensitivity to $\mathrm{H}_{2} \mathrm{O}_{2}$ and paraquat [360]. These mutants also have increased $\mathrm{H}_{2} \mathrm{O}_{2}$ levels in their mitochondria associated with protein damage and alteration of different cellular pathways [361]. Surprisingly, despite the restricted expression pattern of DJ-1alpha, knocking it down by transgenic RNA interference results in the accumulation of ROS in postmitotic neurons, hypersensitivity to oxidative stress and degeneration of dopaminergic and photoreceptor neurons [362]. DJ-1alpha is also up-regulated in DJ1 beta mutant flies and apparently sufficient to confer protection against paraquat [363]. On the other hand, over-expression of DJ-1beta protects DJ-1alpha/beta knockout flies from oxidative stress, whereas overexpression of C104A DJ-1beta (homologous to human C106A) cannot [357]. Similarly, as described above under the section about PINK1, up-regulation of DJ1 rescues the phenotype of PINK1 deleted flies in a Cys104 dependent manner [333], further pointing to the anti-oxidant function of DJ-1 in this protection. Consistent with these findings, knocking down DJ-1 in nematodes exacerbates the sensitivity of worms to rotenone-induced death [364].

Several mechanisms can mediate the protective effects of DJ-1 against oxidative stress. As an ROS quencher, DJ-1 shifts to a more acidic form upon oxidative stress by oxidation of its Cys106 and translocates from the cytoplasm to mitochondria as well as nucleus $[365,366]$. Whether Cys106 oxidation is essential for the localization of DJ-1 to mitochondria in response to oxidative stress is controversial [346, 365, 366]. But Cys106 oxidation to cysteine sulfinic acid is necessary for DJ-1 to exert its cytoprotective activity and to bind to the DNA-binding region of other proteins [367]. Further oxidation, however, is believed to render it inactive [368]. Levels of oxidized DJ-1 in the SN 
of mice increase dose-dependently following MPTP administration [369]. Further, significant elevation of Cys106-oxidized DJ-1 has been reported in erythrocytes of untreated PD patients [370], and more acidic isoforms of DJ-1 have been detected in extracts of frontal cortex from patients with sporadic PD compared to control subjects [371].

Besides quenching ROS, DJ-1 enhances cellular glutathione levels through increased expression of the enzyme glutamate cysteine ligase. This effect is lost when glutathione synthesis is inhibited, but is reversible by adding exogenous glutathione [372]. DJ-1 may also act as an oxidative-stress-induced chaperone inducer through up-regulating HSP70, which binds to and stabilizes alpha-synuclein, preventing its aggregation and subsequent cell death [368, 373, 374]. Accordingly, over-expression of DJ1 in dopaminergic cells inhibits protein aggregation and cytotoxicity caused by alpha-synuclein [372]. DJ-1 can also increase the expression of vesicular monoamine transporter-2 (VMAT2) [347, 375]. Since VMAT2 keeps cytoplasmic dopamine levels in check by storing the transmitter in synaptic vesicles, DJ-1 decreases intracellular ROS levels and enhances the resistance of cells against dopamine toxicity. Reducing DJ-1 levels has the opposite effect [347]. Thus, DJ-1 can confer neuroprotection through up-regulating VMAT2 by enabling the rapid and efficient transport of dopamine from the cytoplasm to vesicles. DJ-1 also contributes to mitochondrial quality control. Its loss of function is associated with reduced mitochondrial membrane potential and fragmentation [376], while over-expression of wild-type DJ-1 is associated with elongated mitochondria along with enhanced resistance to oxidative insults [335, 376-378]. ROS scavengers rescue this phenotype [379]. Accordingly, mitochondria isolated from DJ-1 deficient mice produce more ROS compared with controls, and lymphoblasts derived from DJ-1 mutant PD patients exhibit abnormal mitochondrial morphology [379].

Another proposed mechanism for the antioxidant function of DJ-1 is through the stabilization of Nrf2 by preventing the association of this transcription regulator with its inhibitor Keap1 [380]. Over-expression of DJ-1 in SH-SY5Y cells results in increased Nrf2 protein levels, promotes its translocation to the nucleus and enhances its recruitment onto the antioxidant response element (ARE) in the promoter of the redox regulator thioredoxin-1 (Trx1). Knocking down Nrf2 abolishes DJ-1 mediated Trx1 induction and cytoprotection against hydrogen peroxide [381].
DJ-1 acts as a potent inhibitor of the Daxx/Apoptosis Signal Regulating Kinase 1 (ASK1) cell-death signaling pathway [382]. Under basal conditions, DJ-1 present in the nucleus interacts with Daxx preventing the translocation of this death protein to the cytoplasm and its interaction with ASK1 following insults including oxidative stress. This process would block the activation of ASK1 and hence cell death [382]. Additionally, DJ-1 controls ASK1 activity by modulating the interaction between ASK1 and Trx1. ASK1 is bound to Trx 1 under basal conditions, but the two dissociate upon oxidant insult allowing ASK1 activation and subsequent cell death. Wild-type DJ-1 interacts with ASK1 blocking its oxidant-induced dissociation from Trx1, while the PD linked L166P mutant cannot. Cys106 of DJ-1 is required for its ability to regulate ASK-1/Trx1 interaction [383]. Consistent with the death signaling activity of ASK1, MPTP challenge of cultured cells and mice results in activation of this kinase, while knocking out ASK1 in mice ameliorates MPTP toxicity and suppresses the neuroinflammatory response in the SNpc and striatum [384]. Collectively, these results indicate that the DJ-1-ASK1 pathway plays an important role in the anti-oxidant response.

\section{LRRK2}

LRRK2 is a large multi-domain protein linked to autosomal dominant PD. Disease associated mutations are identified in almost all its domains but are commonest in its kinase domain leading to increased kinase activity [153, 385-392]. As kinase activity is required for cell-death, it is suggested that LRRK2 enzymatic activity plays an important role in the pathogenesis of PD [391, 392].

LRRK2 is predominantly a cytoplasmic protein, although it can also be associated with the outer mitochondrial membrane, raising the possibility that the increased kinase activity of mutant LRRK2 might directly affect mitochondrial function [153, 393]. In agreement with this hypothesis, increased LRRK2 activity leads to neuronal death via mitochondrialdependent apoptosis, while lack of LRRK2 has a protective effect on mitochondrial dysfunction [394]. Over-expression of wild-type or mutant LRRK2 with enhanced kinase activity in various cell lines or primary neurons leads to mitochondrial fragmentation and dysfunction associated with increased ROS generation and increased susceptibility to $\mathrm{H}_{2} \mathrm{O}_{2}[149,395,396]$. Further, iPSC cells from LRRK2 mutant human subjects exhibit increased vulnerability to $\mathrm{MPP}^{+}$[325]. 
A proposed mechanism for the increased vulnerability of LRRK2 mutant cells to oxidative stress is via the kinase-dependent interaction between LRRK2 and dynamin-like protein (DLP1), which facilitates DLP1 translocation to mitochondria and subsequent mitochondrial fission [149, 397]. Another mechanism is through the interaction of LRRK2 with peroxiredoxin 3 (PRDX3), which is a mitochondrial member of the antioxidant family of thioredoxin peroxidases. Mutations in the LRRK2 kinase domain increase phosphorylation of PRDX3 leading to decreased peroxidase activity, increased ROS production, and increased cell death. Notably, postmortem analysis of brains from PD patients carrying the G2019S mutation in the kinase domain of LRRK2 has shown marked increase in phosphorylated PRDX3 compared to normal brains [398].

Animal models used to study the effect of LRRK2 against oxidative stress have shown contradictory results, perhaps suggesting different pathways in LRRK2-mediated neuroprotection. Caenorhabditis elegans over-expressing human wild-type LRRK2 in neurons survive longer in response to rotenone or paraquat than wild-type worms, while PD-linked LRRK2 mutants that have increased kinase activity or even kinase dead mutant provide less protection than wild-type LRRK2 [399]. Knock down of the endogenous ortholog of LRRK2 in the worm reduces survival associated with mitochondrial impairment. LRRK2 mutations may also selectively exacerbate the vulnerability of dopaminergic neurons to oxidative stress [399] as these neurons are more influenced by the model than the survival of the whole worm [399]. Similarly, Drosophila expressing human wildtype but not mutant LRRK2 are protected against rotenone [400], while flies expressing mutant LRRK2 are more sensitive to $\mathrm{H}_{2} \mathrm{O}_{2}$ [401]. Furthermore, adding curcumin to flies' diet protects them against $\mathrm{H}_{2} \mathrm{O}_{2}$ and increases their survival [401]. A proposed mechanism for this protective effect is increased expression of LRRK2 [402]. Despite the limitations of overexpression paradigms, one can conclude from these results that LRRK2 has an important role in mitochondrial function and in the capacity of the cell to keep oxidative stress in check. Contrary to worm and fly models, mouse models do not support a mitochondrial pathway for LRRK2 neuroprotection. This is because LRRK2 knock-out mice have not yielded the expected results as they have a normal dopaminergic system and do not exhibit significant differences in their susceptibility to MPTP when compared with wild-type mice [403]. These observations in mice may be due to compensatory changes during ontogeny [403].

\section{THERAPEUTIC IMPLICATIONS OF OXIDATIVE STRESS IN PD}

Knowledge gained about the link between oxidative stress and the pathogenesis of PD has two therapeutic implications. The first is whether currently used drugs have any impact on this process, either positive or negative. And the second is the potential to develop new drugs that might be able to mitigate oxidative stress and by doing so slow disease progression. Extensive investigations into the first question have shown no solid evidence for clinically relevant impact, while the success of the second scenario remains elusive.

PD remains an incurable disease despite repeated efforts to test potential neuroprotective strategies. The gold standard treatment, L-dopa, is transformed to dopamine in dopaminergic neurons by dopa-decarboxylase raising some concerns about the potential toxicity of long term L-dopa therapy. But these concerns were largely laid to rest from the ELLDOPA trial (Earlier versus Late Levodopa), which showed that L-dopa in combination with a peripheral decarboxylase inhibitor is the most effective treatment for $\mathrm{PD}$, with its early use ameliorating the motor symptoms over time [404, 405]. Thus, despite the toxicity of dopamine in culture, there is no evidence for $\mathrm{L}$ dopa having such deleterious effects in the human brain.

Dopamine agonists have been suggested to have neuroprotective and antioxidant effects [406]. For example, pramipexole protects MES 23.5 cells against hydrogen peroxide, dopamine and L-dopa induced toxicity [407]. It also reduces lipid peroxidation and minimizes injury to the SN of MPTP lesioned mice [408]. The antioxidant effect of pramipexole independent of its dopamine receptor agonist property can be responsible for its neuroprotective action [409]. It can reduce the levels of oxygen radicals produced by $\mathrm{MPP}^{+}$both when incubated with SH-SY5Y cells and when perfused into the rat striatum [410]. Similarly, ropinirole protects mice against 6-OHDA by increasing glutathione levels [411, 412]. However, in several clinical trials using the dopamine agonists ropinirole and pramipexole, no significant advantage was seen in slowing progression of motor symptoms although imaging studies suggested a benefit of the agonists over L-dopa [413-425]. This is believed to be due to the drugs affecting the imaging studies rather than true neuroprotection.

MAO-B inhibitors prevent MPTP toxicity to nigral dopaminergic neurons in animal models through inhibition of $\mathrm{MPP}^{+}$generation [426]. Both clinically used 
agents, selegiline and rasagiline, have symptomatic antiparkinson effects [48, 427-430], which have confounded interpretation of clinical trials designed with the goal to study their potential neuroprotective effects. For example, the DATATOP study tested the effects of selegiline and found a significant delay in the time until enough disability developed to require the initiation of L-dopa therapy. But this was attributed to the symptomatic effect of selegiline rather than true neuroprotection [431]. Similarly, early use of rasagiline had greater improvement in motor disability compared with later introduction of the drug $[432,433]$. But again questions about the symptomatic effect of the drug and about the delayed-start study design have made it difficult to provide conclusive evidence for neuroprotection by MAO-B inhibitors [432, 434-436].

Among agents that might alleviate oxidative stress, creatine is an antioxidant involved in the inhibition of the opening of the mitochondrial permeability pore and affects mitochondrial energy production [437-439]. In mice, creatine has been shown to protect against MPTP-induced dopaminergic depletion in the SN [440]. Two phase II studies of creatine in PD patients have yielded contradictory results, one failing to show efficacy [441] while the other reporting about $40 \%$ less worsening of motor Unified PD Rating Scale scores at one year [442]. In a follow up phase II NET-PD futility study, creatine use at 18 months did not show safety concerns, but the phase III trial was recently terminated due to lack of statistically significant difference from placebo [443, 444].

Other attempts to use compounds with antioxidant properties in PD have included tocopherol (vitamin E), vitamin C, Coenzyme Q10, docosahexaenoic acid (DHA), Ginkgo biloba, or polyphenols found in green tea [431, 445-451]. None of these have yielded convincing evidence for neuroprotective efficacy. In addition to selegiline, the DATATOP study studied the effects of the antioxidant tocopherol in patients with early PD and found no impact on disease progression [431]. Recently, ketogenic diet has been suggested as a potential therapy in neurological diseases, since the mitochondrial Complex II activator D-betahydroxybutyrate, a ketone body, has been shown to increase cellular GSH content, decrease intracellular ROS production induced by $\mathrm{H}_{2} \mathrm{O}_{2}$, inhibit apoptosis and enhance cell viability [452]. Although this diet has not been studied in animal models of PD yet, a caloric restriction diet conferred resistance to MPTP in mice, rats and rhesus monkeys [453-455]. Interestingly, an uncontrolled study of five patients with PD placed on a ketogenic diet for 28 days reported a $43 \%$ improvement in their Unified PD Rating Scale scores [456].

\section{CONCLUSION}

Although the mechanisms involved in the pathogenesis and progression of PD are not fully understood, there is overwhelming evidence that oxidative stress plays an important role in dopaminergic neuronal degeneration. Since the maintenance of redox potential is an important factor for neuronal survival, it is not surprising that any disruption in this potential might interfere with other biological processes in the cell, ultimately leading to cell death. It is also likely that the interplay between these various mechanisms contribute to neurodegeneration in PD as a feed forward scenario where primary insults lead to oxidative stress, which damages key cellular pathogenetic proteins and disrupts lipid membranes that in turn cause more ROS production. In the brain, ROS comes mainly from dopamine metabolism, mitochondrial dysfunction and neuroinflammation. Therefore, the protective mechanisms involved in the regulation of these processes have been an area of considerable research focus in recent years. In addition, the study of PD-related proteins in combination with experimental studies using animal models has yielded important insights into the molecular pathways of neuronal degeneration and highlighted previously unknown mechanisms by which oxidative stress contributes to PD. The results obtained so far have been used to design therapeutic approaches. However, despite encouraging results in animal models, a number of attempts in clinical trials to date have failed to demonstrate an impact on disease progression. The incomplete representation of the disease phenotype in the various animal models, the time of treatment onset, heterogeneity of the disease subtypes all likely contribute to this dearth of therapeutic progress. Failures from anti-oxidant compounds and strategies tested to date should guide future newer approaches.

\section{ACKNOWLEDGMENTS}

V.D. is a postdoctoral fellow supported by a grant from the American Parkinson Disease Association. E.J. is supported by NIH grant NS070898. M.M.M. is the William Dow Lovett Professor of Neurology and is supported by NIH grants NS059869, NS073994 and AT006868 and by the Michael J. Fox Foundation for Parkinson's Research. 


\section{CONFLICT OF INTEREST}

None.

\section{REFERENCES}

[1] Fahn S, \& Sulzer D (2004) Neurodegeneration and neuroprotection in Parkinson disease. Neuro Rx, 1, 139-154.

[2] Sulzer D, \& Surmeier DJ (2013) Neuronal vulnerability, pathogenesis, and Parkinson's disease. Mov Disord, 28, 4150.

[3] Schapira AH, \& Jenner P (2011) Etiology and pathogenesis of Parkinson's disease. Mov Disord, 26, 1049-1055.

[4] Zhu J, \& Chu CT (2010) Mitochondrial dysfunction in Parkinson's disease. J Alzheimers Dis, 20(Suppl 2), S325S334.

[5] Parker WD, Parks JK, \& Swerdlow RH (2008) Complex I deficiency in Parkinson's disease frontal cortex. Brain Res, 16, 215-218.

[6] Jenner P, \& Olanow W (2006) The pathogenesis of cell death in Parkinson's disease. Neurol, 66, S24-S36.

[7] Beal MF (2005) Mitochondria take center stage in aging and neurodegeneration. Ann Neurol, 58, 495-505.

[8] Jenner P (2003) Oxidative stress in Parkinson's disease. Ann Neurol, 53(Suppl 3), S26-S36; discussion S36-S28.

[9] Yoritaka A, Hattori N, Uchida K, Tanaka M, Stadtman E, \& Mizuno Y (1996) Immunohistochemical detection of 4 hydroxynonenal protein adducts in Parkinson disease. Proc Natl Acad Sci U S A, 93, 2696-2701.

[10] Floor E, \& Wetzel M (1998) Increased protein oxidation in human substantia nigra pars compacta in comparison with basal ganglia and prefrontal cortex measured with an improved dinitrophenylhydrazine assay. J Neurochem, 70, 268-275.

[11] Alam ZI, Jenner A, Daniel SE, Lees AJ, Cairns N, Marsden CD, Jenner P, \& Halliwell B (1997) Oxidative DNA damage in the Parkinsonian brain: An apparent selective increase in 8-hydroxyguanine levels in substantia nigra. $J$ Neurochem, 69, 1196-1203.

[12] Zhang J, Perry G, Smith MA, Robertson D, Olson SJ, Graham DG, \& Montine TJ (1999) Parkinson's disease is associated with oxidative damage to cytoplasmic DNA and rna in substantia nigra neurons. Am J Pathol, 154, 14231429.

[13] Richardson JR, Quan Y, Sherer TB, Greenamyre JT, \& Miller GW (2005) Paraquat neurotoxicity is distinct from that of MPTP and rotenone. Toxicol Sci, 88, 193-201.

[14] Callio J, Oury T, \& Chu C (2005) Manganese superoxide dismutase protects against 6-hydroxydopamine injury in mouse brains. J Biol Chem, 6, 18356-18542.

[15] Vila M, \& Przedborski S (2003) Targeting programmed cell death in neurodegenerative diseases. Nat Rev Neurosci, 4 365-375.

[16] Perier C, Bovè J, Vila M, \& Przedborski S (2003) The rotenone model of Parkinson's disease. Trends Neurosci, 26 345-346.

[17] Fukushima T, Gao T, Tawara T, Hojo N, Isobe A, \& Yamane Y (1997) Inhibitory effect of nicotinamide to paraquat toxicity and the reaction site on complex I. Arch Toxicol, 71, 633-637.

[18] Lin MT, \& Beal MF (2006) Mitochondrial dysfunction and oxidative stress in neurodegenerative diseases. Nature, $\mathbf{4 4 3}$ 787-795.
[19] Beal MF (2003) Bioenergetic approaches for neuroprotection in Parkinson's disease. Ann Neurol, 53(Suppl 3), S39-47; discussion S47-38.

[20] Andersen JK (2004) Oxidative stress in neurodegeneration: Cause or consequence? Nat Med, 10(Suppl), S18-S25.

[21] Smith DG, Cappai R, \& Barnham KJ (2007) The redox chemistry of the Alzheimer's disease amyloid beta peptide. Biochim Biophys Acta, 1768, 1976-1990.

[22] Muller FL, Liu Y, \& Van Remmen H (2004) Complex III releases superoxide to both sides of the inner mitochondrial membrane. J Biol Chem, 279, 49064-49073.

[23] Valko M, Leibfritz D, Moncol J, Cronin MT, Mazur M, \& Telser J (2007) Free radicals and antioxidants in normal physiological functions and human disease. Int $J$ Biochem Cell Biol, 39, 44-84.

[24] Malkus KA, Tsika E, \& Ischiropoulos H (2009) Oxidative modifications, mitochondrial dysfunction, and impaired protein degradation in Parkinson's disease: How neurons are lost in the Bermuda triangle. Mol Neurodegene, 4, 24.

[25] Carr AC, McCall MR, \& Frei B (2000) Oxidation of LDL by myeloperoxidase and reactive nitrogen species : Reaction pathways and antioxidant protection. Arteriosclerosis, Thrombosis, and Vascular Biology, 20, 1716-1723.

[26] Szabo C, Ischiropoulos H, \& Radi R (2007) Peroxynitrite: Biochemistry, pathophysiology and development of therapeutics. Nat Rev Drug Discov, 6, 662-680.

[27] Vincent VA, Tilders FJ, \& Van Dam AM (1998) Production, regulation and role of nitric oxide in glial cells. Mediators Inflamm, 7, 239-255.

[28] Murphy S, Simmons ML, Agullo L, Garcia A, Feinstein DL, Galea E, Reis DJ, Minc-Golomb D, \& Schwartz JP (1993) Synthesis of nitric oxide in CNS glial cells. Trends Neurosci, 16, 323-328.

[29] Hirsch EC, Breidert T, Rousselet E, Hunot S, Hartmann A, \& Michel PP (2003) The role of glial reaction and inflammation in Parkinson's disease. Ann N Y Acad Sci, 991, 214-228.

[30] Tieu K, Ischiropoulos H, \& Przedborski S (2003) Nitric oxide and reactive oxygen species in Parkinson's disease. IUBMB Life, 55, 329-335.

[31] Mander P, Borutaite V, Moncada S, \& Brown GC (2005) Nitric oxide from inflammatory-activated glia synergizes with hypoxia to induce neuronal death. J Neurosci Res, 79 , 208-215.

[32] Bal-Price A, \& Brown GC (2001) Inflammatory neurodegeneration mediated by nitric oxide from activated glia-inhibiting neuronal respiration, causing glutamate release and excitotoxicity. J Neurosci, 21, 6480-6491.

[33] Park S, Geddes TJ, Javitch JA, \& Kuhn DM (2003) Dopamine prevents nitration of tyrosine hydroxylase by peroxynitrite and nitrogen dioxide: Is nitrotyrosine formation an early step in dopamine neuronal damage? J Biol Chem, 278, 28736-28742.

[34] Ara J, Przedborski S, Naini A, Jackson-Lewis V, Trifiletti R, Horwitz J, \& Ischiropoulos H (1998) Inactivation of tyrosine hydroxylase by nitration following exposure to peroxynitrite and 1-methyl-4-phenyl-1,2,3,6-tetrahydropyridine (MPTP). Proc Natl Acad Sci U S A, 95, 7659-7663.

[35] Hunot S, Boissièrs F, Faucheux B, Brugg B, Mouatt-Prigent A, Agid Y, \& Hirsch E (1996) Nitric oxide synthase and neuronal vulnerability in Parkinson's disease. Neurosci, 72, 355-363.

[36] Eve DJ NA, Kingsbury AE, Hewson EL, Daniel SE, Lees AJ, Marsden CD, \& Foster OJ (1998) Basal ganglia neuronal nitric oxide synthase mRNA expression in Parkinson's disease. Brain Res Mol Brain Res, 63, 62-71. 
[37] Liberatore GT, Jackson-Lewis V, Vukosavic S, Mandir AS, Vila M, McAuliffe WG, Dawson VL, Dawson TM, \& Przedborski S (1999) Inducible nitric oxide synthase stimulates dopaminergic neurodegeneration in the MPTP model of Parkinson disease. Nat Med, 5, 403-409.

[38] Schulz JB, Matthews RT, Muqit MM, Browne SE, \& Beal MF (1995) Inhibition of neuronal nitric oxide synthase by 7 nitroindazole protects against MPTP-induced neurotoxicity in mice. J Neurochem, 64, 936-939.

[39] Hantraye P, Brouillet E, Ferrante R, Palfi S, Dolan R, Matthews RT, \& Beal MF (1996) Inhibition of neuronal nitric oxide synthase prevents MPTP-induced parkinsonism in baboons. Nat Med, 2, 1017-1021.

[40] Pimentel C, Batista-Nascimento L, Rodrigues-Pousada C, \& Menezes RA (2012) Oxidative stress in Alzheimer's and Parkinson's diseases: Insights from the yeast saccharomyces cerevisiae. Oxid Med Cell Longe, 2012, 132146.

[41] Fomenko DE, Koc A, Agisheva N, Jacobsen M, Kaya A, Malinouski M, Ruthetford JC, Siu KL, Winge DR, \& Gladyshev VN (2011) Thiol peroxidases mediate specific genome-wide regulation of the gene expression in response to hydrogen peroxide. Proc Natl Acad Sci U S A, 198, 27292734.

[42] Alam ZI, Jenner A, Daniel SE, Lees AJ, Marsden CD, Jenner P, \& Halliwell B (1997) A generalised increase in protein carbonyls in the brain in Parkinson's but not incidental Lewy Body disease. J Neurochem, 69, 1326-1329.

[43] Johnson WM, Wilson-Delfosse AL, \& Mieyal JJ (2012) Dysregulation of glutathione homeostasis in neurodegenerative diseases. Nutrients, 4, 1399-1440.

[44] Dumont M, \& Beal MF (2011) Neuroprotective strategies involving ROS in Alzheimer's disease. Free Radic Biol Med, 51, 1014-1026.

[45] Yan MH, Wang X, \& Zhu X (2011) Mitochondrial defects and oxidative stress in Alzheimer disease and Parkinson disease. Free Radic Biol Med, 62, 90-101.

[46] Liu X, Yamada N, Maruyama W, \& Osawa T (2008) Formation of dopamine adducts derived from brain polyunsaturated fatty acids: Mechanism for Parkinson disease. J Biol Chem, 283, 34887-34895.

[47] Munoz P, Huenchuguala S, Paris I, \& Segura-Aguilar J (2012) Dopamine oxidation and autophagy. Parkinsons Di, 2012, 920953.

[48] Jenner P, \& Langston JW (2011) Explaining adagio: A critical review of the biological basis for the clinical effects of rasagiline. Mov Disord, 26, 2316-2323.

[49] Riederer P, Konradi C, Schay V, Kienzl E, Birkmayer G, Danielczyk W, Sofic E, \& Youdim MB (1987) Localization of MAO-A and MAO-B in human brain: A step in understanding the therapeutic action of L-deprenyl. Adv Neurol, 45, 111-118.

[50] Saura J, Andrés N, Andrade C, Ojuel J, Eriksson K, \& Mahy N (1997) Biphasic and region-specific MAO-B response to aging in normal human brain. Neurobiol Aging, 18, 497507.

[51] Youdim MB, Edmondson D, \& Tipton KF (2006) The therapeutic potential of monoamine oxidase inhibitors. Nat Rev Neurosci, 7, 295-309.

[52] Fowler JS, Volkow N, Wang GJ, Logan J, Pappas N, Shea C, \& MacGregor R (1997) Age-related increases in brain monoamine oxidase $\mathrm{B}$ in living healthy human subjects. Neurobiol Aging, 18, 431-435.

[53] Inazu M, Takeda H, Ikoshi H, Uchida Y, Kubota N, Kiuchi Y, Oguchi K, \& Matsumiya T (1999) Regulation of dopamine uptake by basic fibroblast growth factor and epidermal growth factor in cultured rat astrocytes. Neurosci Res, 34, 235-244.

[54] Semenoff D, \& Kimelberg H (1985) Autoradiography of high affinity uptake of catecholamines by primary astrocyte cultures. brain Res, 385, 125-136.

[55] Kimelberg HK, \& Katz DM (1986) Regional differences in 5 -hydroxytryptamine and catecholamine uptake in primary astrocyte cultures. J Neurochem, 47, 1647-1652.

[56] Nagatsu T, \& Sawada M (2006) Molecular mechanism of the relation of monoamine oxidaes inhibitors to Parkinson's disease: Possible implications of glial cells. J Neural Transm, 71, 53-65.

[57] Kumar MJ, \& Andersen JK (2004) Perspectives on MAO-B in aging and neurological disease - where do we go from here? Mol Neurobiol, 30, 77-89.

[58] Mallajosyula JK, Kaur D, Chinta SJ, Rajagopalan S, Rane A, Nicholls DG, Di Monte DA, Macarthur H, \& Andersen JK (2008) MAO-B elevation in mouse brain astrocytes results in Parkinson's pathology. PLoS One, 3, e1616.

[59] Hastings TG (2009) The role of dopamine oxidation in mitochondrial dysfunction: Implications for Parkinson's disease. J Bioenerg Biomembr, 41, 469-472.

[60] Norris EH, Giasson BI, Hodara R, Xu S, Trojanowski JQ, Ischiropoulos H, \& Lee VM (2005) Reversible inhibition of alpha-synuclein fibrillization by dopaminochromemediated conformational alterations. J Biol Chem, 280, 21212-21219.

[61] Zecca L, Wilms H, Geick S, Claasen JH, Brandenburg LO, Holzknecht C, Panizza ML, Zucca FA, Deuschl G, Sievers J, \& Lucius R (2008) Human neuromelanin induces neuroinflammation and neurodegeneration in the rat substantia nigra: Implications for Parkinson's disease. Acta Neuropathol 116, 47-55.

[62] Spencer JP, Jenner P, Daniel SE, Lees AJ, Marsden DC, \& Halliwell B (1998) Conjugates of catecholamines with cysteine and GSH in Parkinson's disease: Possible mechanisms of formation involving reactive oxygen species. $J$ Neurochem, 71, 2112-2122.

[63] Uhl GR, Li S, Takahashi N, Itokawa K, Lin Z, Hazama M, \& Sora I (2000) The VMAT2 gene in mice and humans: Amphetamine responses, locomotion, cardiac arrhythmias, aging, and vulnerability to dopaminergic toxins. FASEB $J$, 14, 2459-2465.

[64] Hastings TG (1995) Enzymatic oxidation of dopamine: The role of prostaglandin H synthase. J Neurochem, 64, 919-924.

[65] Graham D (1978) Pathways for catecholamines in the genesis of neuromelanin and cytotoxic quinones. Mol Pharmacol, 14, 633-643.

[66] Double KL (2012) Neuronal vulnerability in Parkinson's disease. Parkinsonism \& Related Disorders, 18, S52-S54.

[67] Fedorow H, Tribl F, Halliday G, Gerlach M, Riederer P, \& Double KL (2005) Neuromelanin in human dopamine neurons: Comparison with peripheral melanins and relevance to Parkinson's disease. Prog Neurobiol, 75, 109-124.

[68] Kastner A, Hirch EC, Lejeune O, Javoy-Agid F, Rascol O, \& Agid Y (1992) Is the vulnerability of neurons in the substantia nigra of patients with Parkinson's disease related to their neuromelanin content? J Neurochem, 59, 10801089.

[69] Hirsch E, Graybiel A, \& Agid YA (1998) Melanized dopaminergic neurons are differentially susceptible to degeneration in Parkinson's disease. Nature, 334, 345-348.

[70] Halliday GM, Ophof A, Broe M, Jensen PH, Kettle E, Fedorow H, Cartwright MI, Griffiths FM, Shepherd CE, \& Double KL (2005) Alpha-synuclein redistributes to neu- 
romelanin lipid in the substantia nigra early in Parkinson's disease. Brain, 128, 2654-2664.

[71] German DC, Manaye KF, Sonsalla PK, \& Brooks BA (1992) Midbrain dopaminergic cell loss in Parkinson's disease and MPTP-induced parkinsonism: Sparing of calbindin-D28kcontaining cells. Ann N Y Acad Sci, 648, 42-62.

[72] Kish SJ, Shannak K, \& Hornykiewicz O (1988) Uneven pattern of dopamine loss in the striatum of patients with idiopathic Parkinson's disease. Pathophysiologic and clinical implications. $N$ Engl Med, 318, 876-880.

[73] Fasano M, Bergamasco B, \& Lopiano L (2006) Is neuromelanin changed in Parkinson's disease? Investigations by magnetic spectroscopies. J Neural Transm, 113, 769-774.

[74] Bohic S, Murphy K, Paulus W, Cloetens P, Salomé M, Susini J, \& Double K (2008) Intracellular chemical imaging of the developmental phases of human neuromelanin using synchrotron X-ray microspectroscopy. Anal Chem, 80, 9557-9566.

[75] Double KL, Gerlach M, Schünemann V, Trautwein AX, Zecca L, Gallorini M, Youdim MB, Riederer P, \& Ben-Shachar D (2003) Iron-binding characteristics of neuromelanin of the human substantia nigra. Biochem Pharmacol, 66, 489-494.

[76] Faucheux BA, Martin ME, Beaumont C, Hauw JJ, Agid Y, \& Hirsch EC (2003) Neuromelanin associated redoxactive iron is increased in the substantia nigra of patients with Parkinson's disease. J Neurochem, 86, 1142-1148.

[77] Jellinger KA, Kienzl E, Rumpelmaier G, Paulus W, Riederer P, Stachelberger H, Youdim MB, \& Ben-Shachar D (1993) Iron and ferritin in substantia nigra in Parkinson's disease. Adv neurol, 60, 267-272.

[78] Gründemann J, Schlaudraff F, \& Liss B (2011) UV-laser microdissection and mRNA expression analysis of individual neurons from postmortem Parkinson's disease brains. Methods Mol Biol 755, 363-374.

[79] Li J, Yang J, Zhao P, Li S, Zhang R, Zhang X, Liu D, \& Zhang B (2012) Neuromelanin enhances the toxicity of alpha-synuclein in SK-N-SH cells. J Neural Transm, 119 685-691.

[80] Xuan Q, Xu SL, Lu DH, Yu S, Zhou M, Uéda K, Cui YQ, Zhang BY, \& Chan P (2011) Increased expression of $\alpha$-synuclein in aged human brain associated with neuromelanin accumulation. J Neural Transm, 118, 1575-1583.

[81] Karlsson O, \& Lindquist NG (2013) Melanin affinity and its possible role in neurodegeneration. J Neural Transm. [Epub ahead of print].

[82] Pearce RK, Owen A, Daniel S, Jenner P, \& Marsden CD (1997) Alterations in the distribution of glutathione in the substantia nigra in Parkinson's disease. J Neural Transm, 104, 661-677.

[83] Riederer P, Sofic E, Rausch WD, Schmidt B, Reynolds GP, Jellinger K, \& Youdim MB (1989) Transition metals, ferritin, glutathione, and ascorbic acid in parkinsonian brains. J Neurochem, 52, 515-520.

[84] Perry TL, Godin DV, \& Hansen S (1982) Parkinson's disease: A disorder due to nigral glutathione deficiency? Neurosci Lett, 33, 305-310.

[85] Sian J, Dexter D, Lees AJ, Daniel S, Agid Y, Javoy-Agid F, Jenner P, \& Marsden CD (1994) Alterations in glutathione levels in Parkinson's disease and other neurodegenerative disorders affecting basal ganglia. Ann Neurol, 36, 348-355.

[86] Sofic E, Lange K, Jellinger K, \& Riederer P (1992) Reduced and oxidized glutathione in the substantia nigra of patients with Parkinson's disease. Neuroscience letters, 142, 128130.
[87] Jones DP, \& Go YM (2010) Redox compartmentalization and cellular stress. Diabetes Obes Metab, 12(Suppl 2), 116125 .

[88] Wadey AL, Muyderman H, Kwek PT, \& Sims NR (2009) Mitochondrial glutathione uptake: Characterization in isolated brain mitochondria and astrocytes in culture. $J$ Neurochem, 109(Suppl 1), 101-108.

[89] Genestra M (2007) Oxyl radicals, redox-sensitive signalling cascades and antioxidants. Cell Signal, 19, 1807-1819.

[90] Chinta SJ, Kumar MJ, Hsu M, Rajagopalan S, Kaur D, Rane A, Nicholls DG, Choi J, \& Andersen JK (2007) Inducible alterations of glutathione levels in adult dopaminergic midbrain neurons result in nigrostriatal degeneration. J Neurosci, 27, 13997-14006.

[91] Chinta SJ, \& Andersen JK (2008) Redox imbalance in Parkinson's disease. Biochim Biophys Acta, 1780, 13621367.

[92] Orth M, \& Schapira AH (2002) Mitochondrial invlvement in Parkinson's disease. Neurochem Int, 40, 533-541.

[93] Jomova K, Vondrakova D, Lawson M, \& Valko M (2010) Metals, oxidative stress and neurodegenerative disorders. Mol Cell Biochem, 345, 91-104.

[94] Garrido M, Tereshchenko Y, Zhevtsova Z, Taschenberger G, Bahr M, \& Kugler S (2011) Glutathione depletion and overproduction both initiate degeneration of nigral dopaminergic neurons. Acta Neuropathol, 121, 475-485.

[95] Sabens EA, Distler AM, \& Mieyal JJ (2010) Levodopa deactivates enzymes that regulate thiol-disulfide homeostasis and promotes neuronal cell death: Implications for therapy of Parkinson's disease. Biochemistry, 49, 2715-2724.

[96] Chai YC, Ashraf SS, Rokutan K, Johnston RB, \& Thomas JA (1994) S-thiolation of individual human neutrophil proteins including actin by stimulation of the respiratory burst: Evidence against a role for glutathione disulfide. Arch Biochem Bioph, 310, 273-281.

[97] Kil IS, \& Park JW (2005) Regulation of mitochondrial NADP+-dependent isocitrate dehydrogenase activity by glutathionylation. J Biol Chem, 280, 10846-10854.

[98] Sabens EA, Steller KM, \& Mieyal JJ (2011) Levodopa activates apoptosis signaling kinase 1 (ASK1) and promotes apoptosis in a neuronal model: Implications for the treatment of Parkinson's disease. Chem Res Toxicol, 24, 1644-1652.

[99] Chae HZ, Rhee SG, Chock PB, Stadtman ER, \& Yim MB (1994) On the protective mechanism of the thiolspecific antioxidant enzyme against the oxidative damage of biomolecules. J Biol Chem, 269, 1621-1626.

[100] Kwon SJ, Park JW, Choi WK, Kim IH, \& Kin K (1994) Inhibition of metal-catalyzed oxidation systems by a yeast protector protein in the presence of thioredoxin. Biochem Biophys Res Commun, 201, 8-15.

[101] Jo SH, Son MK, Koh HJ, Lee SM, Song IH, Kim YO, Lee YS, Jeong KS, Kim WB, Park JW, Song BJ, \& Huh TL (2001) Control of mitochondrial redox balance and cellular defense against oxidative damage by mitochondrial NADP+-dependent isocitrate dehydrogenase. J Biol Chem, 276, 16168-16176

[102] Sian-Hulsmann J, Mandel S, Youdim MB, \& Riederer P (2011) The relevance of iron in the pathogenesis of Parkinson's disease. J Neurochem, 118, 939-957.

[103] Double KL, Ben-Shachar D, Youdin MB, Zecca L, Riederer P, \& Gerlach M (2002) Influence of neuromelanin on oxidative pathways within the human substantia nigra. Neurotox Teratol, 24, 621-628.

[104] Dexter DT, Carayon A, Javoy-Agid F, Agid Y, Wells FR, Daniel SE, Lees AJ, Jenner P, \& Marsden CD (1991) Alter- 
ations in the levels of iron, ferritin and other trace metals in Parkinson's disease and other neurodegenerative diseases affecting the basal ganglia. Brain, 114, 1953-1975.

[105] Kosta P, Argyropoulou MI, Markoula S, \& Konitsiotis S (2006) MRI evaluation of the basal ganglia size and iron content in patients with Parkinson's disease. J Neurol, 253, 26-32.

[106] Castellani RJ, Siedlak SL, Perry G, \& Smith MA (2000) Sequestration of iron by Lewy Bodies in Parkinson's disease. Acta Neuropathol, 100, 111-114.

[107] Schipper HM, Liberman A, \& Stopa EG (1998) Neural heme oxygenase-1 expression in idiopathic Parkinson's disease. Exp Neur, 150, 60-68.

[108] Beard JL, Wiesinger JA, \& Connor JR (2003) Pre- and postweaning iron deficiency alters myelination in spraguedawley rats. Developmental Neuroscience, 25, 308-315.

[109] Jomova K, \& Valko M (2011) Advances in metal-induced oxidative stress and human disease. Toxicology, 283, 65-87.

[110] Nunez MT, Urrutia P, Mena N, Aguirre P, Tapia V, \& Salazar $\mathrm{J}$ (2012) Iron toxicity in neurodegeneration. Biometals, 25, 761-776.

[111] Saffari Y, \& Sadrzadeh SMH (2004) Iron and brain disorders. Pathology Patterns Reviews, 121, 65-70.

[112] Dexter DT, Siann J, Rose S, Hindmarsh JG, Mann VM, Cooper JM, Wells FR, Daniel SE, Lees AJ, \& Schapira AH (1994) Indices of oxidative stress and mitochondrial function in individuals with incidental Lewy Body disease. Ann Neurol 35, 38-44.

[113] Kaur D, \& Andersen J (2004) Does cellular iron dysregulation play a causative role in Parkinson's disease? Ageing Res Rev, 3, 327-343.

[114] Berg D, Gerlach M, Youdim M, Bouble K, Zecca L, Riederer P, \& Becker G (2001) Brain iron pathways and their relevance to Parkinson's disease. J Neurochem, 79, 225-236.

[115] Kaur D, Peng J, Chinta SJ, Rajagopalan S, Di Monte DA, Cherny RA, \& Andersen JK (2007) Increased murine neonatal iron intake results in parkinson-like neurodegeneration with age. Neurobiol Aging, 28, 907-913.

[116] Sziráki I, Mohanakumar KP, Rauhala P, Kim HG, Yeh KJ, \& Chiueh CC (1998) Manganese: A transition metal protects nigrostatal neurons from oxidative stress in the ironinduced animal model of parkinsonisn. Neuroscience, $\mathbf{8 5}$, 1101-1111.

[117] Lan J, \& Jiang DH (1997) Desferrioxamine and vitamin e protect against iron and MPTP-induced neurodegeneration in mice. J Neural Transm, 104, 469-481.

[118] Surmeier DJ, Guzman JN, Sanchez-Padilla J, \& Schumacker PT (2011) The role of calcium and mitochondrial oxidant stress in the loss of substantia nigra pars compacta dopaminergic neurons in Parkinson's disease. Neuroscience, 198, 221-231.

[119] Dryanovski DI, Guzman JN, Xie Z, Galteri DJ, VolpicelliDaley LA, Lee VM, Miller RJ, Schumacker PT, \& Surmeier DJ (2013) Calcium entry and alpha-synuclein inclusions elevate dendritic mitochondrial oxidant stress in dopaminergic neurons. J Neurosci, 33, 10154-10164.

[120] Khaliq ZM, \& Bean BP (2010) Pacemaking in dopaminergic ventral tegmental area neurons: Depolarizing drive from background and voltage-dependent sodium conductances. $J$ Neurosci, 30, 7401-7413.

[121] Mosharov EV, Larsen KE, Kanter E, Phillips KA, Wilson K, Schmitz Y, Krantz DE, Kobayashi K, Edwards RH, \& Sulzer D (2009) Interplay between cytosolic dopamine, calcium, and alpha-synuclein causes selective death of substantia nigra neurons. Neuron, 62, 218-229.
[122] Montine TJ, Neely MD, Quinn JF, Beal MF, Markesbery WR, Roberts LJ, \& Morrow JD (2002) Lipid peroxidation in aging brain and Alzheimer's disease. Free Radic Biol Med 33 620-626.

[123] Mattson MP (1998) Modification of ion homeostasis by lipid peroxidation: Roles in neuronal degeneration and adaptive plasticity. Trends Neurosci, 20, 53-57.

[124] Montine KS, Quinn JF, Zhang J, Fessel JP, Roberts LJ, 2nd, Morrow JD, \& Montine TJ (2004) Isoprostanes and related products of lipid peroxidation in neurodegenerative diseases. Chem Phys Lipids, 128, 117-124.

[125] Liu W, Kato M, Akhand AA, Hayakawa A, Suzuki H, Miyata T, Kurokawa K, Hotta Y, Ishiakawa N, \& Nakashima I (2000) 4-hydroxynonenal induces a cellular redox statusrelated activation of the caspase cascade for apoptotic cell death. Journal Cell Science, 113, 635-641.

[126] Schmidt H, Grune T, Müller R, Siems WG, \& Wauer RR (1996) Increased levels of lipid peroxidation products malondialdehyde and 4-hydroxynonenal after perinatal hypoxia. Pedriatric Research, 40, 15-20.

[127] Picklo MJ, Amarnath V, McIntyre JO, Graham DG, \& Montine TJ (1999) 4-hydroxy-2(E)-nonenal inhibits cns mitochondrial respiration at multiple sites. J Neurochem, 72, 1617-1624.

[128] Turrens JF (2003) Mitochondrial formation of reactive oxygen species. J Physiol, 552, 335-344.

[129] Barja G, \& Herrero A (1998) Localization at complex i and mechanism of the higher free radical production of brain nonsynaptic mitochondria in the short-lived rat than in the longevous pigeon. J Bioenerg Biomembr, 30, 235-243.

[130] Turrens JF, \& Boveris A (1980) Generation of superoxide anion by the NADH dehydrogenase of bovine heart mitochondria. Biochem J, 191, 421-427.

[131] Murphy MP (2009) How mitochondria produce reactive oxygen species. Biochem J, 417, 1-13.

[132] Kirkinezos IG, \& Moraes CT (2001) Reactive oxygen species and mitochondrial diseases. Semin Cell Dev Biol, 12, 449-457.

[133] Fridovich I (1989) Superoxide dismutases. An adaptation to a paramagnetic gas. J Biol Chem, 264, 7761-7764.

[134] Brandt U (2006) Energy converting NADH:Quinone oxidoreductase (complex I). Annu Rev Biochem, 75, 69-92.

[135] Votyakova TV, \& Reynolds I (2001) DeltaPsi(m)-dependent and -independent production of reactive oxygen species by rat brain mitochondria. J Neurochem, 79, 266-277.

[136] Crofts A (2004) The cytochrome bc1 complex: Function in the context of structure. Annu Rev Physiol, 66, 689733.

[137] Finkel T, \& Holbrook NJ (2000) Oxidants, oxidative stress and the biology of ageing. Nature, 408, 239-247.

[138] Barja G (1999) Mitochondrial oxygen radical generation and leak: Sites of production in states 4 and 3, organ specificity, and relation to aging and longevity. J Bioenerg Biomembr, 31, 347-366.

[139] Langston JW, Ballard P, Tetrud JW, \& Irwin I (1983) Chronic parkinsonism in humans due to a product of meperidineanalog synthesis. Science, 219, 979-980.

[140] Keeney PM, Xie J, Capaldi RA, \& Bennett JP, Jr. (2006) Parkinson's disease brain mitochondrial complex I has oxidatively damaged subunits and is functionally impaired and misassembled. $J$ Neurosci, 26, 5256-5264.

[141] Shults CW, Haas RH, Passov D, \& Beal MF (1997) Coenzyme Q10 levels correlate with the activities of complexes I and II/III in mitochondria from parkinsonian and nonparkinsonian subjects. Ann Neurol, 42, 261-264. 
[142] Schapira AH, Cooper JM, Dexter D, Jenner P, Clark JB, \& Marsden CD (1989) Mitochondrial complex I deficiency in Parkinson's disease. Lance, 1, 1269.

[143] Elstner M, Morris CM, Heim K, Bender A, Mehta D, Jaros E, Klopstock T, Meitinger T, Turnbull DM, \& Prokisch $\mathrm{H}$ (2011) Expression analysis of dopaminergic neurons in Parkinson's disease and aging links transcriptional dysregulation of energy metabolism to cell death. Acta Neuropathol, 122, 75-86.

[144] Krige D, Carroll MT, Cooper JM, Marsden CD, \& Schapira AH (1992) Platelet mitochondrial function in Parkinson's disease. The Royal Kings and Queens Parkinson disease research group. Ann Neurol, 32, 782-788.

[145] Bindoff LA, Birch-Machin MA, Cartlidge NE, Parker WD, Jr. \& Turnbull DM (1991) Respiratory chain abnormalities in skeletal muscle from patients with Parkinson's disease. J Neurol Sci, 104, 203-208.

[146] Parker WD, Boyson SJ, \& Parks JK (1989) Abnormalities of the electron transport chain in idiopathic Parkinson's disease. Ann Neurol, 26, 719-723.

[147] Parker DW, Jr., Parks JK, \& Swerdlow RH (2008) Complex I deficiency in Parkinson's disease frontal cortex. Brain Res, 1189, 215-218.

[148] Taylor DJ, Krige D, Barnes PR, Kemp GJ, Carroll MT, Mann VM, Cooper JM, Marsden CD, \& Schapira AH (1994) A 31P magnetic resonance spectroscopy study of mitochondrial function in skeletal muscle of patients with Parkinson's disease. J Neurol Sci, 125, 7-81.

[149] Wang X, Yan MH, Fujioka H, Liu J, Wilson-Delfosse A, Chen SG, Perry G, Casadesus G, \& Zhu X (2012) LRRK2 regulates mitochondrial dynamics and function through direct interaction with DLP1. Hum Mol Genet, 21, 19311944

[150] Wood-Kaczmar A, Gandhi S, Yao Z, Abramov AY, Miljan EA, Keen G, Stanyer L, Hargreaves I, Klupsch K, Deas E, Downward J, Mansfield L, Jat P, Taylor J, Heales S, Duchen MR, Latchman D, Tabrizi SJ, \& Wood NW (2008) PINK1 is necessary for long term survival and mitochondrial function in human dopaminergic neurons. PLoS One, $\mathbf{3}$, e2455.

[151] Gautier CA, Kitada T, \& Shen J (2008) Loss of PINK1 causes mitochondrial functional defects and increased sensitivity to oxidative stress. Proc Natl Acad Sci U S A, 105, 11364-11369.

[152] Clark IE, Dodson MW, Jiang C, Cao JH, Huh JR, Seol JH, Yoo SJ, Hay BA, \& Guo M (2006) Drosophila PINK1 is required for mitochondrial function and interacts genetically with parkin. Nature, 441, 1162-1166.

[153] West AB, Moore DJ, Biskup S, Bugayenko A, Smith WW, Ross CA, Dawson VL, \& Dawson TM (2005) Parkinson's disease-associated mutations in leucine-rich repeat kinase 2 augment kinase activity. Proc Natl Acad Sci U S A, 102, 16842-16847.

[154] Palacino JJ, Sagi D, Goldberg MS, Krauss S, Motz C, Wacker M, Klose J, \& Shen J (2004) Mitochondrial dysfunction and oxidative damage in parkin-deficient mice. $J$ Biol Chem 279, 18614-18622.

[155] Gusdon AM, Zhu J, Van Houten B, \& Chu CT (2012) ATP13A2 regulates mitochondrial bioenergetics through macroautophagy. Neurobiol Dis, 45, 962-972.

[156] Olanow CW, \& McNaught KS (2006) Ubiquitin-proteasome system and Parkinson's disease. Mov Disord, 21, 1806 1823.

[157] Davies KJA (2001) Degradation of oxidized proteins by the 20s proteasome. Biochimie, 83, 301-310.
[158] Davies KJA, \& Goldberg AL (1987) Proteins damaged by oxygen radicals are rapidly degraded in extracts of red blood cells. J Biol Chem, 262, 8227-8234.

[159] Hansen RE, Roth D, \& Winther JR (2009) Quantifying the global cellular thiol-disulfide status. Proc Natl Acad Sci U S A, 106, 422-427.

[160] Collier TJ, Kanaan NM, \& Kordower JH (2011) Ageing as a primary risk factor for Parkinson's disease: Evidence from studies of non-human primates. Nat Rev Neurosci, 12, 359-366.

[161] Bennett MC, Bishop JF, Leng Y, Chock PB, Chase TN, \& Mouradian MM (1999) Degradation of alpha-synuclein by proteasome. J Biol Chem, 274, 33855-33858.

[162] Hashimoto M, Hsu LJ, Xia Y, Takeda A, Sisk A, Sundsmo M, \& Masliah E (1999) Oxidative stress induces amyloidlike aggregate formation of NACP/alpha-synuclein in vitro. Neurochem, 10, 717-721.

[163] McNaught KS, \& Jenner P (2001) Proteasomal function is impaired in substantia nigra in Pdisease. Neurosci Lett, 297, 191-194.

[164] Shamoto-Nagai M, Maruyama W, Kato Y, Isobe K, Tanaka M, Naoi M, \& Osawa T (2003) An inhibitor of mitochondrial complex I, rotenone, inactivates proteasome by oxidative modification and induces aggregation of oxidized proteins in SH-SY5Y cells. J Neurosci Res, 74, 589-597.

[165] McNaught StP, Belizaire R, Isacson O, Jenner P, \& Olanow CW (2003) Altered proteasomal function in sporadic Parkinson's disease. Exp Neurol, 179, 38-46.

[166] Tofaris GK, Razzaq A, Ghetti B, Lilley KS, \& Spillantini MG (2003) Ubiquitination of alpha-synuclein in Lewy Bodies is a pathological event not associated with impairment of proteasome function. $J$ Biol Chem, 278, 44405-44411.

[167] Hyun D-H, Lee M, Halliwell B, \& Jenner P (2004) Proteasomal inhibition causes the formation of protein aggregates containing a wide range of proteins, including nitrated proteins. J Neurochem, 86, 363-373.

[168] Betarbet R, Sherer TB, \& Greenamyre JT (2005) Ubiquitinproteasome system and Parkinson's diseases. Exp Neurol, 191(Suppl 1), S17-S27.

[169] Block ML, Zecca L, \& Hong JS (2007) Microglia-mediated neurotoxicity: Uncovering the molecular mechanisms. Nat Rev Neurosci, 8, 57-69.

[170] Ceulemans AG, Zgavc T, Kooijman R, Hachimi-Idrissi S, Sarre S, \& Michotte Y (2010) The dual role of the neuroinflammatory response after ischemic stroke: Modulatory effects of hypothermia. $J$ Neuroinflammatio, $7,74$.

[171] Cheret C, Gervais A, Lelli A, Colin C, Amar L, Ravassard P, Mallet J, Cumano A, Krause KH, \& Mallat M (2008) Neurotoxic activation of microglia is promoted by a nox 1dependent NADPH oxidase. J Neurosci, 28, 12039-12051.

[172] Martin HL, \& Teismann P (2009) Glutathione-a review on its role and significance in Parkinson's disease. FASEB $J$, 23, 3263-3272

[173] Gerhard A, Pavese N, Hotton G, Turkheimer F, Es M, Hammers A, Eggert K, Oertel W, Banati RB, \& Brooks DJ (2006) In vivo imaging of microglial activation with [11C](R)PK11195 pet in idiopathic Parkinson's disease. Neurobiol Dis, 21, 404-412.

[174] Hunot S, Dugas N, Faucheux B, Hartmann A, Tardieu M, Debré P, Agid Y, Dugas B, \& Hirsch EC (1999) FcRII/CD23 is expressed in Parkinson's disease and induces, in vitro, production of nitric oxide and tumor necrosis factor-alpha in glial cells. J Neurosci, 19, 3440-3447.

[175] Mogi M, Harada M, Narabayashi H, Inagaki H, Minami M, \& Nagatsu T (1996) Interleukin (IL)-1beta, IL-2, IL-4, IL- 
6 and transforming growth factor-alpha levels are elevated in ventricular cerebrospinal fluid in juvemile parkinsonism and Parkinson's disease. Neurosci Lett, 211, 13-16.

[176] Herrera AJ, Castano A, Venero JL, Cano J, \& Machado A (2000) The single intranigral injection of lps as a new model for studying the selective effects of inflammatory reactions on dopaminergic system. Neurobiol Dis, 7, 429-447.

[177] Iravani MM, Leung CC, Sadeghian M, Haddon CO, Rose S, \& Jenner P (2005) The acute and the long-term effects of nigral lipopolysaccharide administration on dopaminergic dysfunction and glial cell activation. Eur J Neurosci, 22, 317-330.

[178] Iravani MM, Sadeghian M, Leung CC, Jenner P, \& Rose S (2012) Lipopolysaccharide-induced nigral inflammation leads to increased IL-1beta tissue content and expression of astrocytic glial cell line-derived neurotrophic factor. $\mathrm{Neu}$ rosci Lett, 510, 138-142.

[179] McNaught KS, \& Jenner P (2000) Altered glial function causes neuronal death and increases neuronal susceptibility to 1-methyl-4-phenylpyridinium- and 6-hydroxydopamineinduced toxicity in astrocyte/ventral mesencephalic cocultures. J Neurochem, 73, 2469-2476.

[180] McNaught KS, Mytilineou C, JnoBaptiste R, Yabut J, Shashidharan P, Jenner P, \& Olanow CW (2002) Impairment of the ubiquitin-proteasome system causes dopaminergic cell death and inclusion body formation in ventral mesencephalic cultures. J Neurochem, 81, 301-306.

[181] Qian L, Flood PM, \& Hong JS (2010) Neuroinflammation is a key player in Parkinson's disease and a prime target for therapy. J Neural Transm, 117, 971-979.

[182] Hamza TH, Zabetian CP, Tenesa A, Laederach A, Montimurro J, Yearout D, Kay DM, Doheny KF, Paschall J, Pugh E, Kusel VI, Collura R, Roberts J, Griffith A, Samii A, Scott WK, Nutt J, Factor SA, \& Payami H (2010) Common genetic variation in the hla region is associated with late-onset sporadic Parkinson's disease. Nat Genet, 42, 781-785.

[183] Hernandez-Romero MC, Delgado-Cortes MJ, Sarmiento M, de Pablos RM, Espinosa-Oliva AM, Arguelles S, Bandez MJ, Villaran RF, Maurino R, Santiago M, Venero JL, Herrera AJ, Cano J, \& Machado A (2012) Peripheral inflammation increases the deleterious effect of CNS inflammation on the nigrostriatal dopaminergic system. Neurotoxicology, 33, 347-360.

[184] Rentzos M, Nikolaou C, Andreadou E, Paraskevas GP, Rombos A, Zoga M, Tsoutsou A, Boufidou F, Kapaki E, \& Vassilopoulos D (2007) Circulating interleukin-15 and rantes chemokine in Parkinson's disease. Acta Neurol Scand, 116, 374-379.

[185] Dexter DT, \& Jenner P (2013) Parkinson disease: From pathology to molecular disease mechanisms. Free Radic Biol Med, 62, 132-144.

[186] Schapira AH (2008) Mitochondria in the aetiology and pathogenesis of Parkinson's disease. Lancet Neurol, 7, 97109.

[187] Gibb WR, \& Lees A (1991) Anatomy, pigmentation, ventral and dorsal subpopulations of the substantia nigra, and differential cell death in Parkinson's disease. J Neurol Neurosurg Psychiatry, 54, 388-396.

[188] Calne DB, \& Langston J (1983) Aetiology of Parkinson's disease. Lancet, 2, 1457-1459.

[189] Greaves LC, Reeve A, Taylor RW, \& Turnbull DM (2012) Mitochondrial DNA and disease. J Pathol, 226, 274-286.

[190] Boumezbeur F, Mason G, de Graaf RA, Behar KL, Cline GW, Shulman GI, Rothman DL, \& Petersen KF (2010) Altered brain mitochondrial metabolism in healthy aging as assessed by in vivo magnetic resonance spectroscopy. J Cereb Blood Flow Metab, 30, 211-221.

[191] Reeve AK, Krishnan KJ, \& Turnbull DM (2008) Age related mitochondrial degenerative disorders in humans. Biotechnol $J, \mathbf{3}, 750-756$.

[192] Reeve AK, Krishnan KJ, Elson JL, Morris CM, Bender A, Lightowlers RN, \& Turnbull DM (2008) Nature of mitochondrial DNA deletions in substantia nigra neurons. Am J Hum Genet, 82, 228-235.

[193] Elstner M, Müller SK, Leidolt L, Laub C, Krieg L, SchlaudraffF, Liss B, Morris C, Turnbull DM, Masliah E, Prokisch H, Klopstock T, \& Bender A (2011) Neuromelanin, neurotransmitter status and brainstem location determine the differential vulnerability of catecholaminergic neurons to mitochondrial DNA delections. Molecular Brain, 4, $1-10$.

[194] Bender A, Krishnan KJ, Morris CM, Taylor GA, Reeve AK, Perry RH, Jaros E, Hersheson JS, Betts J, Klopstock T, Taylor RW, \& Turnbull DM (2006) High levels of mitochondrial DNA deletions in substantia nigra neurons in aging and Parkinson disease. Nat Genet, 38, 515-517.

[195] Kraytsberg Y, Kudryavtseva E, McKee AC, Geula C, Kowall NW, \& Khrapko K (2006) Mitochondrial DNA deletions are abundant and cause functional impairment in aged human substantia nigra neurons. Nat Genet, 38, 518-520.

[196] Beckman KB, \& Ames BN (1998) The free radical theory of aging matures. Physiol Rev, 78, 547-581.

[197] Abramov AY, Smulders-Srinivasan TK, Kirby DM, AcinPerez R, Enriquez JA, Lightowlers RN, Duchen MR, \& Turnbull DM (2010) Mechanism of neurodegeneration of neurons with mitochondrial DNA mutations. Brain, 133, 797-807.

[198] Tuppen HA, Blakely EL, Turnbull DM, \& Taylor RW (2010) Mitochondrial DNA mutations and human disease. Biochim Biophys Acta, 1797, 113-128.

[199] Surmeier DJ, Guzman JN, Sanchez-Padilla J, \& Goldberg JA (2011) The Origins of Oxidant Stress in Parkinson's Disease and Therapeutic Strategies. Antioxid Redox Signal, 14, 1289-1301.

[200] Wallace DC (2010) Mitochondrial DNA mutations in disease and aging. Environ Mol Mutagen, 51, 440-450.

[201] Shigenaga MK HT, \& Ames BN (1994) Oxidative damage and mitochondrial decay in aging. Proc Natl Acad Sci U S A, 91, 10771-10778.

[202] Cuervo AM (2008) Autophagy and aging: Keeping that old broom working. Trends Genet, 24, 604-612.

[203] Hubbard VM, Valdor R, Macian F, \& Cuervo AM (2012) Selective autophagy in the maintenance of cellular homeostasis in aging organisms. Biogerontology, 13, 21-35.

[204] Weisskopf MG, Knekt P, O'Reilly EJ, Lyytinen J, Reunanen A, Laden F, Altshul L, \& Ascherio A (2010) Persistent organochlorine pesticides in serum and risk of Parkinson disease. Neurol, 74, 1055-1061.

[205] Richardson JR, Shalat SL, Buckley B, Winnik B, O'Suilleabhain P, Diaz-Arrastia R, Reisch J, \& German DC (2009) Elevated serum pesticide levels and risk of Parkinson disease. Arch Neurol, 66, 870-875.

[206] Elbaz A, Clavel J, Rathouz PJ, Moisan F, Galanaud JP, Delemotte B, \& Alpérovitch A, Tzourio C (2009) Professional exposure to pesticides and Parkinson disease. Ann Neurol, 66, 494-504.

[207] Corrigan FM, Wienburg CL, Shore RF, Daniel SE, \& Mann D (2000) Organochlorine insecticides in substantia nigra in Parkinson's disease. J Toxicol Environ Health A, 59, 229234. 
[208] Corrigan FM WC, Shore RF, Daniel SE, \& Mann D (2000) Organochlorine insecticides in substantia nigra in Parkinson's disease. J Toxicol Environ Health A, 59, 229-234.

[209] Kamel F (2013) Epidemiology. Paths from pesticides to Parkinson's. Science, 341, 722-723.

[210] Lee PC, Bordelon Y, Bronstein J, \& Ritz B (2012) Traumatic brain injury, paraquat exposure, and their relationship to Parkinson disease. Neurol, 79, 2061-2066.

[211] Gatto NM, Cockburn M, Bronstein J, Manthripragada AD, \& Ritz B (2009) Well-water consumption and Parkinson's disease in rural California. Environ Health Perspect $\mathbf{1 1 7}$ 1912-1918.

[212] Pezzoli G, \& Cereda E (2013) Exposure to pesticides or solvents and risk of Parkinson disease. Neurol, 80, 2035 2041.

[213] Tanner CM, Kamel F, Ross GW, Hoppin JA, Goldman SM, Korell M, Marras C, Bhudhikanok GS, Kasten M, Chade AR, Comyns K, Richards MB, Meng C, Priestley B, Fernandez HH, Cambi F, Umbach DM, Blair A, Sandler DP, \& Langston JW (2011) Rotenone, paraquat, and Parkinson's disease. Environ Health Perspect, 119, 866-872.

[214] Tanner CM, Ross GW, Jewell SA, Hauser RA, Jankovic J, Factor SA, Bressman S, Deligtisch A, Marras C, Lyons KE, Bhudhikanok GS, Roucoux DF, Meng C, Abbott RD, \& Langston JW (2009) Occupation and risk of parkinsonism: A multicenter case-control study. Arch Neurol, 66, 11061113.

[215] Costello S, Cockburn M, Bronstein J, Zhang X, \& Ritz B (2009) Parkinson's disease and residential exposure to maneb and paraquat from agricultural applications in the central valley of California. Am J Epidemiol, 169, 919-926.

[216] Bus J, \& Gibson JE (1984) Paraquat: Model for Oxidant Initiated Toxicity. Environ Health Perspect, 55, 37-46.

[217] Abeliovich A, Schmitz Y, Farinas I, Choi-Lundberg D, Ho W, Castillo P, Shinsky N, Verdugo J, Armanini M, Ryan A, Hynes M, Philips H, Sulzer D, \& Rosenthal A (2000) Mice lacking alpha-synuclein display functional deficits in the nigrostriatal dopamine system. Neuron, 25, 239-252.

[218] Yavich L, Tanila H, Vepsalainen S, \& Jakala P (2004) Role of alpha-synuclein in presynaptic dopamine recruitment. $J$ Neurosci, 24, 11165-11170.

[219] Yavich L, Jakala P, \& Tanila H (2006) Abnormal compartmentalization of norepinephrine in mouse dentate gyrus in alpha-synuclein knockout and A30P transgenic mice. J Neurochem, 99, 724-732.

[220] Ahn TB, Kim SY, Kim JY, Park SS, Lee DS, Min HJ, Kim YK, Kim SE, Kim JM, Kim HJ, Cho J, \& Jeon BS (2008) Alpha-synuclein gene duplication is present in sporadic Parkinson disease. Neurology, 70, 43-49.

[221] Chartier-Harlin MC, Kachergus J, Roumier C, Mouroux V, Douay X, Lincoln S, Levecque C, Larvor L, Andrieux J, Hulihan M, Waucquier N, Defebvre L, Amouyel P, Farrer M, \& Destée A (2004) Alpha-synuclein locus duplication as a cause of familial Parkinson's disease. Lancet, 364, 11671169.

[222] Lee MK, Stirling W, Xu Y, Xu X, Qui D, Mandir AS, Dawson TM, Copeland NG, Jenkins NA, \& Price DL (2002) Human alpha-synuclein-harboring familial Parkinson's disease-linked Ala-53 $\rightarrow$ Thr mutation causes neurodegenerative disease with alpha-synuclein aggregation in transgenic mice. Proc Natl Acad Sci U S A, 99, 8968-8973.

[223] Singleton AB, Farrer M, Johnson J, Singleton A, Hague S, Kachergus J, Hulihan M, Peuralina T, Dutra A, Nussbaum R, Lincoln S, Crawley A, Hanson M, Marganore D, Adler C, Cookson MR, Muenter M, Baptista M, Miller D, Blancato J,
Hardy J, \& Gwinn-Hardy K (2003) Alpha-synuclein locus triplication causes Parkinson's disease. Science 302, 841.

[224] Polymeropoulos MH (1997) Mutation in the -synuclein gene identified in families with Parkinson's disease. Science, 276, 2045-2047.

[225] Spillantini MG, Schmidt ML, Lee VM, Trojanowski JQ, Jakes R, \& Goedert M (1997) Alpha-synuclein in Lewy Bodies. Nature, 388, 839-840.

[226] Paxinou E, Chen Q, Weisse M, Giasson BI, Norris EH, Rueter SM, Trojanowski JQ, Lee V, \& Ischiropoulos H (2001) Induction of alpha-synuclein aggregation by intracellular nitrative insult. J Neurol, 15, 8053-8061.

[227] Ischiropoulos H, \& Beckman JS (2003) Oxidative stress and nitration in neurodegeneration: Cause, effect, or association? J Clin Invest, 111, 163-169.

[228] Conway KA, Rochet JC, Bieganski RM, \& Lansbury PT Jr. (2001) Kinetic stabilization of the alpha-synuclein protofibril by a dopamine-alpha-synuclein adduct. Science, 294, 1346-1349.

[229] Ostrerova-Golts N, Petrucelli L, Hardy J, Lee JM, Farer M, \& Wolozin B (2000) The A53T a-synuclein mutation increases iron-dependent aggregation and toxicity. $\mathrm{J} \mathrm{Neu}$ rosci, 20, 6048-6054.

[230] Kakimura J, Kitamura Y, Takata K, Kohno Y, Nomura Y, \& Taniguchi T (2001) Release and aggregation of cytochrome $\mathrm{c}$ and alpha-synuclein are inhibited by the antiparkinsonian drugs, talipexole and pramipexole. Eur J Pharmacol, 417, 59-67.

[231] Sangchot P, Sharma S, Chetsawang B, Porter J, Govitrapong P, \& Ebadi M (2002) Deferoxamine attenuates iron-induced oxidative stress and prevents mitochondrial aggregation and alpha-synuclein translocation in SK-N-SH cells in culture. Dev Neurosci, 24, 143-153.

[232] Xu S, Zhou M, Yu S, Cai Y, Zhang A, Ueda K, \& Chan P (2006) Oxidative stress induces nuclear translocation of cterminus of alpha-synuclein in dopaminergic cells. Biochem Biophys Res Commun, 342, 330-335.

[233] Goers J, Manning-Bog A, McCormack AL, Millett IS, Doniach S, Di Monte DA, Uversky VN, \& Fink AL (2003) Nuclear localization of R-synuclein and its interaction with histones. Biochem, 42, 8465-8471.

[234] Sherer TB, Kim J-H, Betarbet R, \& Greenamyre JT (2003) Subcutaneous rotenone exposure causes highly selective dopaminergic degeneration and $\alpha$-synuclein aggregation. Exp Neurol, 179, 9-16.

[235] Binukumar BK, Bal A, Kandimalla RJ, \& Gill KD (2010) Nigrostriatal neuronal death following chronic dichlorvos exposure: Crosstalk between mitochondrial impairments, alpha synuclein aggregation, oxidative damage and behavioral changes. Mol Brai, 3, 35 .

[236] Fernagut PO, Hutson CB, Fleming SM, Tetreaut NA, Salcedo J, Masliah E, \& Chesselet MF (2007) Behavioral and histopathological consequences of paraquat intoxication in mice: Effects of alpha-synuclein over-expression. Synapse, 61, 991-1001.

[237] Junn E, \& Mouradiam MM (2002) Human a-synuclein overexpression increases intracellular reactive oxygen species levels and susceptibility to dopamine. Neurosci Lett, 320, 146-115.

[238] Winklhofer KF, \& Haass C (2010) Mitochondrial dysfunction in Parkinson's disease. Biochim Biophys Acta, 1802, 29-44.

[239] Orth M, Tabrizi SJ, Tomlinson C, Messmer K, Korlipara LV, Schapira AH, \& Cooper JM (2004) G209A mutant alpha-synuclein expression specifically enhances dopamine 
induced oxidative damage. Neurochem Int, 45, 669676.

[240] Tabrizi SJ, Orth M, Wilkinson JM, Taanman JW, Warner TT, Cooper JM, \& Schapira AH (2000) Expression of mutant alpha-synuclein causes increased susceptibility to dopamine toxicity. Hum Mol Genet, 9, 2683-2689.

[241] Nieto M, Gil-Bea FJ, Dalfo E, Cuadrado M, Cabodevilla F, Sanchez B, Catena S, Sesma T, Ribe E, Ferrer I, Ramirez MJ, \& Gomez-Isla T (2006) Increased sensitivity to MPTP in human alpha-synuclein A30P transgenic mice. Neurobiol Aging, 27, 848-856.

[242] Piltonen M, Savolainen M, Patrikainen S, Baekelandt V, Myohanen TT, \& Mannisto PT (2013) Comparison of motor performance, brain biochemistry and histology of two A30P alpha-synuclein transgenic mouse strains. Neurosci, 231, $157-168$.

[243] Song DD, Shults CW, Sisk A, Rockenstein E, \& Masliah E (2004) Enhanced substantia nigra mitochondrial pathology in human $\alpha$-synuclein transgenic mice after treatment with MPTP. Exp Neurol, 186, 158-172.

[244] Klivenyi P, Siwek D, Gardian G, Yang L, Starkov A, Cleren C, Ferrante RJ, Kowall NW, Abeliovich A, \& Beal MF (2006) Mice lacking alpha-synuclein are resistant to mitochondrial toxins. Neurobiol Dis, 21, 541-548.

[245] Dauer W, Kholodilov N, Vila M, Trillat AC, Goodchild R, Larsen KE, Staal R, Tieu K, Schmitz Y, Yuan CA, Rocha M, Jackson-Lewis V, Hersch S, Sulzer D, Przedborski S, Burke $\mathrm{R}$, \& Hen R (2002) Resistance of alpha-synuclein null mice to the parkinsonian neurotoxin MPTP. Proc Natl Acad Sci U S A, 99, 14524-14529.

[246] Volles MJ, \& Lansbury PJ (2002) Vesicle permeabilization by protofibrillar alpha-synuclein is sensitive to Parkinson's disease-linked mutations and occurs by a pore-like mechanism. Biochemistry, 41, 4595-4602.

[247] Mosharov EV, Staal RG, Bove J, Prou D, Hananiya A, Markov D, Poulsen N, Larsen KE, Moore CM, Troyer MD, Edwards RH, Przedborski S, \& Sulzer D (2006) Alphasynuclein overexpression increases cytosolic catecholamine concentration. J Neurosci, 26, 9304-9311.

[248] Hasegawa T, Matsuzaki-Kobayashi M, Takeda A, Sugeno N, Kikuchi A, Furukawa K, Perry G, Smith MA, \& Itoyama Y (2006) Alpha-synuclein facilitates the toxicity of oxidized catechol metabolites: Implications for selective neurodegeneration in Parkinson's disease. FEBS Lett, 580, 21472152.

[249] Ahn BH, Rhim H, Kim SY, Sung YM, Lee MY, Choi JY, Wolozin B, Chang JS, Lee YH, Kwon TK, Chung KC, Yoon SH, Hahn SJ, Kim MS, Jo YH, \& Min DS (2002) Alpha-synuclein interacts with phospholipase d isozymes and inhibits pervanadate-induced phospholipase $\mathrm{d}$ activation in human embryonic kidney-293 cells. J Biol Chem, 277, 12334-12342.

[250] Lotharius J, \& Brundin P (2002) Pathogenesis of Parkinson's disease: Dopamine, vesicles and alpha-synuclein. Nat Rev Neurosci 3, 932-942.

[251] Lee FJ, Liu F, Pristupa ZB, \& Niznik HB (2001) Direct binding and functional coupling of alpha-synuclein to the dopamine transporters accelerate dopamine-induced apoptosis. FASEB J, 15, 916-926.

[252] Wilkaniec A, Strosznajder JB, \& Adamczyk A (2013) Toxicity of extracellular secreted alpha-synuclein: Its role in nitrosative stress and neurodegeneration. Neurochem Int, 62 , 776-783.

[253] Chinta SJ, Mallajosyula JK, Rane A, \& Andersen JK (2010) Mitochondrial alpha-synuclein accumulation impairs com- plex I function in dopaminergic neurons and results in increased mitophagy in vivo. Neurosci Lett, 486, 235-239.

[254] Li WW, Yang R, Guo JC, Ren HM, Zha XL, Cheng JS, \& Cai DF (2007) Localization of alpha-synuclein to mitochondria within midbrain of mice. Neuroreport, 18, 1543-1546.

[255] Elkon H, Don J, Melamed E, Ziv I, Shirvan A, \& Offen D (2002) Mutant and wild-type $\alpha$-synuclein interact with mitochondrial cytochrome c oxidase. J Mol Neurosci, 18, 229-238.

[256] Nakamura K, Nemani VM, Wallender EK, Kaehlcke K, Ott M, \& Edwards RH (2008) Optical reporters for the conformation of alpha-synuclein reveal a specific interaction with mitochondria. J Neurosci, 28, 12305-12317.

[257] Zhang L, Zhang C, Zhu Y, Cai Q, Chan P, Ueda K, Yu S, \& Yang H (2008) Semi-quantitative analysis of alphasynuclein in subcellular pools of rat brain neurons: An immunogold electron microscopic study using a $\mathrm{C}$-terminal specific monoclonal antibody. Brain Res, 1244, 40-52.

[258] Devi L, Raghavendran V, Prabhu BM, Avadhani NG, \& Anandatheerthavarada HK (2008) Mitochondrial import and accumulation of alpha-synuclein impair complex I in human dopaminergic neuronal cultures and Parkinson disease brain. J Biol Chem, 283, 9089-9100.

[259] Shavali S, B-BH, Ebadi M, \& Porter J (2008) Mitochondrial localization of alpha-synuclein protein in alpha-synuclein overexpressing cells. Neurosci Lett, 439, 125-128.

[260] Parihar MS, Parihar A, Fujita M, Hashimoto M, \& Ghafourifar P (2008) Mitochondrial association of alpha-synuclein causes oxidative stress. Cell Mol Life Sci, 65, 1272-1284.

[261] Hashimoto M, Takeda A, Hsu LJ, Takenouchi T, \& Masliah E (1999) Role of cytochrome c as a stimulator of alphasynuclein aggregation in Lewy Body disease. J Bioch Chem, 241, 28849-28852.

[262] Choubey V, Safiulina D, Vaarmann A, Cagalinec M, Wareski P, Kuum M, Zharkovsky A, \& Kaasik A (2011) Mutant A53T alpha-synuclein induces neuronal death by increasing mitochondrial autophagy. J Biol Chem, 286, 10814-10824

[263] Martin LJ, Pan Y, Price AC, Sterling W, Copeland NG, Jenkins NA, Price DL, \& Lee MK (2006) Parkinson's disease alpha-synuclein transgenic mice develop neuronal mitochondrial degeneration and cell death. JNeurosci, 26, 41-50.

[264] Hsu LJ, Sagara Y, Arroyo A, Rockenstein E, Sisk A, Mallory M, Wong J, Takenouchi T, Hashimoto M, \& Masliah E (2000) Alpha-synuclein promotes mitochondrial deficit and oxidative stress. Am J Pathol, 157, 401-410.

[265] Siddiqui A, Chinta SJ, Mallajosyula JK, Rajagopolan S, Hanson I, Rane A, Melov S, \& Andersen JK (2012) Selective binding of nuclear alpha-synuclein to the PGClalpha promoter under conditions of oxidative stress may contribute to losses in mitochondrial function: Implications for Parkinson's disease. Free Radic Biol Med, 53, 993-1003.

[266] Su X, Maguire-Zeiss KA, Giuliano R, Prifti L, Venkatesh K, \& Federoff HJ (2008) Synuclein activates microglia in a model of Parkinson's disease. Neurobiol Aging, 29, 16901701.

[267] Croisier E, Moran LB, Dexter DT, Pearce RK, \& Graeber MB (2005) Microglial inflammation in the parkinsonian substantia nigra: Relationship to alpha-synuclein deposition. J Neuroinflammatio, $2,14$.

[268] Kim YS, \& Joh T (2006) Microglia, major player in the brain inflammation: Their roles in the pathogenesis of Parkinson's disease. Exp Mol Med, 38, 337-347.

[269] Beraud D, Hathaway HA, Trecki J, Chasovskikh S, Johnson DA, Johnson JA, Federoff HJ, Shimoji M, Mhyre TR, \& Maguire-Zeiss KA (2013) Microglial activation and antiox- 
idant responses induced by the Parkinson's disease protein alpha-synuclein. J Neuroimmune Pharmacol, 8, 94-117.

[270] Beraud D, Twomey M, Bloom B, Mittereder A, Ton V, Neitzke K, Chasovskikh S, Mhyre TR, \& Maguire-Zeiss KA (2011) Alpha-synuclein alters toll-like receptor expression. Front Neurosc, 5, 80.

[271] Alvarez-Erviti L, Couch Y, Richardson J, Cooper JM, \& Wood MJ (2011) Alpha-synuclein release by neurons activates the inflammatory response in a microglial cell line. Neurosci Res, 69, 337-342.

[272] Klegeris A, Pelech S, Giasson BI, Maguire J, Zhang H, McGeer EG, \& McGeer PL (2008) Alpha-synuclein activates stress signaling protein kinases in THP-1 cells and microglia. Neurobiol Aging, 29, 739-752.

[273] Thomas MP, Chartrand K, Reynolds A, Vitvitsky V, Banerjee R, \& Gendelman HE (2007) Ion channel blockade attenuates aggregated alpha synuclein induction of microglial reactive oxygen species: Relevance for the pathogenesis of Parkinson's disease. J Neurochem, 100, 503-519.

[274] Zhang W, Dallas S, Zhang D, Guo JP, Pang H, Wilson B, Miller DS, Chen B, Zhang W, McGeer PL, Hong JS, \& Zhang J (2007) Microglial phox and MAC-1 are essential to the enhanced dopaminergic neurodegeneration elicited by A30P and A53T mutant alpha-synuclein. Glia, 55, 11781188.

[275] Seo JH, Rah J, Choi SH, Shin JK, Min K, Kim HS, Park $\mathrm{CH}$, Kim S, Kim EM, Lee SH, Lee S, Suh SW, \& Suh YH (2002) Alpha-synuclein regulates neuronal survival via Bcl2 family expression and PI3/Akt kinase pathway. FASEB J, 16, 1826-1828.

[276] Zhang W, Wang T, Pei Z, Miller DS, Wu X, Block ML, Wilson B, Zhou Y, Hong JS, \& Zhang J (2005) Aggregated alpha-synuclein activates microglia: A process leading to disease progression in Parkinson's disease. FASEB $J, \mathbf{1 9}$, 533-542.

[277] Theodore S, Cao S, McLean PJ, \& Standaert DG (2008) Targeted overexpression of human alpha-synuclein triggers microglial activation and an adaptive immune response in a mouse model of Parkinson disease. J Neuropathol Exp Neurol, 67, 1149-1158.

[278] Su X, Federoff HJ, \& Maguire-Zeiss KA (2009) Mutant alpha-synuclein overexpression mediates early proinflammatory activity. Neurotox Res, 16, 238-254.

[279] Lee KW, Chen W, Junn E, Im JY, Grosso H, Sonsalla PK, Feng X, Ray N, Fernandez JR, Chao Y, Masliah E, Voronkov M, Braithwaite SP, Stock JB, \& Mouradian MM (2011) Enhanced phosphatase activity attenuates alpha-synucleinopathy in a mouse model. J Neurosci, 31, 6963-6971.

[280] Kim YH, Lussier S, Rane A, Choi SW, \& Andersen JK (2011) Inducible dopaminergic glutathione depletion in an alpha-synuclein transgenic mouse model results in agerelated olfactory dysfunction. Neurosci, 172, 379-386.

[281] Kim C, Ho DH, Suk JE, You S, Michael S, Kang J, Joong Lee S, Masliah E, Hwang D, Lee HJ, \& Lee SJ (2013) Neuron-released oligomeric alpha-synuclein is an endogenous agonist of TLR2 for paracrine activation of microglia. Nat Commun, 4, 1562.

[282] Roodveldt C, Christodoulou J, \& Dobson CM (2008) Immunological features of alpha-synuclein in Parkinson's disease. J Cell Mol Med, 12, 1820-1829.

[283] Winner B, Rockenstein E, Lie DC, Aigner R, Mante M, Bogdahn U, Couillard-Despres S, Masliah E, \& Winkler J (2008) Mutant alpha-synuclein exacerbates age-related decrease of neurogenesis. Neurobiol Aging, 29, 913-925.
[284] Gao HM, Zhang F, Zhou H, Kam W, Wilson B, \& Hong JS (2011) Neuroinflammation and alpha-synuclein dysfunction potentiate each other, driving chronic progression of neurodegeneration in a mouse model of Parkinson's disease. Environ Health Perspect, 119, 807-814.

[285] Spillantini MG, Crowther RA, Jakes R, Hasegawa M, \& Goedert M (1998) Alpha-synuclein in filamentous inclusions of lewy bodies from Parkinson's disease and dementia with Lewy Bodies. Proc Natl Acad Sci U S A, 95, 6469-6473.

[286] Fauerbach JA, Yushchenko DA, Shahmoradian SH, Chiu W, Jovin TM, \& Jares-Erijman EA (2012) Supramolecular nonamyloid intermediates in the early stages of alpha-synuclein aggregation. Biophys $J, \mathbf{1 0 2}, 1127-1136$.

[287] Li HT, Du HN, Tang L, Hu J, \& Hu HY (2002) Structural transformation and aggregation of human alpha-synuclein in trifluoroethanol: Non-amyloid component sequence is essential and beta-sheet formation is prerequisite to aggregation. Biopolymers, 64, 221-226.

[288] Uversky VN, Li J, \& Fink AL (2001) Metal-triggered structural transformations, aggregation, and fibrillation of human alpha-synuclein. A possible molecular link between Parkinson's disease and heavy metal exposure. J Biol Chem, 276, 44284-44296.

[289] He Q, Song N, Jia F, Xu H, Yu X, Xie J, \& Jiang H (2013) Role of alpha-synuclein aggregation and the nuclear factor E2-related factor 2/heme oxygenase-1 pathway in iron-induced neurotoxicity. Int J Biochem Cell Biol, 45, 1019-1030.

[290] Febbraro F, Giorgi M, Caldarola S, Loreni F, \& RomeroRamos M (2012) Alpha-synuclein expression is modulated at the translational level by iron. Neuroreport, 23, 576580 .

[291] Martinez-Vicente M, Talloczy Z, Kaushik S, Massey AC, Mazzulli J, Mosharov EV, Hodara R, Fredenburg R, Wu DC, Follenzi A, Dauer W, Przedborski S, Ischiropoulos H, Lansbury PT, Sulzer D, \& Cuervo AM (2008) Dopamine-modified alpha-synuclein blocks chaperonemediated autophagy. J Clin Invest, 118, 777-788.

[292] Luk KC, Kehm VM, Zhang B, O’Brien P, Trojanowski JQ, \& Lee VM (2012) Intracerebral inoculation of pathological alpha-synuclein initiates a rapidly progressive neurodegenerative alpha-synucleinopathy in mice. J Exp Med, 209, 975-986.

[293] Luk KC, Kehm V, Carroll J, Zhang B, O'Brien P, Trojanowski JQ, \& Lee VM (2012) Pathological alpha-synuclein transmission initiates Parkinson-like neurodegeneration in nontransgenic mice. Science, 338, 949-953.

[294] Braidy N, Gai WP, Xu YH, Sachdev P, Guillemin GJ, Jiang XM, Ballard JW, Horan MP, Fang ZM, Chong BH, \& Chan DK (2013) Alpha-Synuclein Transmission and Mitochondrial Toxicity in Primary Human Foetal Enteric Neurons In Vitro. Neurotox Res. [Epub ahead of print].

[295] Bae EJ, Ho DH, Park E, Jung JW, Cho K, Hong JH, Lee HJ, Kim KP, \& Lee SJ (2013) Lipid peroxidation product 4-hydroxy-2-nonenal promotes seeding-capable oligomer formation and cell-to-cell transfer of $\alpha$-synuclein. Antioxid Redox Signal, 18, 770-783.

[296] Zhang Y, Gao J, Chung KK, Huang H, Dawson VL, \& Dawson TM (2000) Parkin functions as an E2-dependent ubiquitin- protein ligase and promotes the degradation of the synaptic vesicle-associated protein, CDCrel-1. Proc Natl Acad Sci U S A, 97, 13354-13359.

[297] Shimura H, Hattori N, Kubo S, Mizuno Y, Asakawa S, Minoshima S, Shimizu N, Iwai K, Chiba T, Tanaka K, \& 
Suzuki T (2000) Familial Parkinson disease gene product, parkin, is a ubiquitin-protein ligase. Nat Gen, 25, 302-305.

[298] Kitada T, Asakawa S, Hattori N, Matsumine H, Yamamura Y, Minoshima S, Yokochi M, Mizuno Y, \& Shimizu N (1998) Mutations in the parkin gene cause autossomal recessive juvenile parkinsonism. Nature, 392, 605-608.

[299] Feany M, \& Pallanck L (2003) Parkin: A multipurpose neuroprotective agent? Neuron, 38, 13-16.

[300] Jiang H, Ren Y, Zhao J, \& Feng J (2004) Parkin protects human dopaminergic neuroblastoma cells against dopamine-induced apoptosis. Hum Mol Genet, 13, 17451754.

[301] Hyun DH, Lee M, Hattori N, Kubo S, Mizuno Y, Halliwell B, \& Jenner P (2002) Effect of wild-type or mutant parkin on oxidative damage, nitric oxide, antioxidant defenses, and the proteasome. J Biol Chem, 277, 28572-28577.

[302] Narendra D, Tanaka A, Suen DF, \& Youle RJ (2008) Parkin is recruited selectively to impaired mitochondria and promotes their autophagy. J Cell Biol, 183, 795-803.

[303] Ziviani E, Tao RN, \& Whitworth AJ (2010) Drosophila parkin requires pink1 for mitochondrial translocation and ubiquitinates mitofusin. Proc Natl Acad Sci U S A, 107, 5018-5023.

[304] Tanaka A, Cleland MM, Xu S, Narendra DP, Suen DF, Karbowski M, \& Youle RJ (2010) Proteasome and p97 mediate mitophagy and degradation of mitofusins induced by parkin. J Cell Biol, 191, 1367-1380.

[305] Chan NC, Salazar AM, Pham AH, Sweredoski MJ, Kolawa NJ, Graham RL, Hess S, \& Chan DC (2011) Broad activation of the ubiquitin-proteasome system by parkin is critical for mitophagy. Hum Mol Genet, 20, 1726-1737.

[306] Whitworth AJ, Theodore DA, Greene JC, Benes H, Wes PD, \& Pallanck LJ (2005) Increased glutathione s-transferase activity rescues dopaminergic neuron loss in a drosophila model of Parkinson's disease. Proc Natl Acad Sci U S A, 102, 8024-8029.

[307] Greene JC, Whitworth AJ, Kuo I, Andrews LA, Feany MB, \& Pallanck LJ (2003) Mitochondrial pathology and apoptotic muscle degeneration in drosophila parkin mutants. Proc Natl Acad Sci U S A, 100, 4078-4083.

[308] Cha GH, Kim S, Park J, Lee E, Kim M, Lee SB, Kim JM, Chung J, \& Cho KS (2005) Parkin negatively regulates JNK pathway in the dopaminergic neurons of drosophila. Proc Natl Acad Sci U S A, 102, 10345-10350.

[309] Stichel CC, Zhu XR, Bader V, Linnartz B, Schmidt S, \& Lubbert H (2007) Mono- and double-mutant mouse models of Parkinson's disease display severe mitochondrial damage. Hum Mol Genet, 16, 2377-2393.

[310] LaVoie MJ, Ostaszewski BL, Weihofen A, Schlossmacher MG, \& Selkoe DJ (2005) Dopamine covalently modifies and functionally inactivates parkin. Nat Med, 11, 12141221.

[311] Chung KK, Thomas B, Li X, Pletnikova O, Troncoso JC, Marsh L, Dawson VL, \& Dawson TM (2004) S-nitrosylation of parkin regulates ubiquitination and compromises parkin's protective function. Science, 304, 1328-1331.

[312] Yonova-Doing E, Atadzhanov M, Quadri M, Kelly P, Shawa N, Musonda ST, Simons EJ, Breedveld GJ, Oostra BA, \& Bonifati V (2012) Analysis of LRRK2, SNCA, parkin, PINK1, and DJ-1 in zambian patients with Parkinson's disease. Parkinsonism Relat Disord, 18, 567-571.

[313] Cookson MR (2012) Parkinsonism due to mutations in PINK1, parkin, and DJ-1 and oxidative stress and mitochondrial pathways. Cold Spring Harb Perspect Med, 2 , a009415.
[314] Valente EM, Abou-Sleiman PM, Caputo V, Muqit MM, Harvey K, Gispert S, Ali Z, Del Turco D, Bentivoglio AR, Healy DG, Albanese A, Nussbaum R, Gonzalez-Maldonado R, Deller T, Salvi S, Cortelli P, Gilks WP, Latchman DS, Harvey RJ, Dallapiccola B, Auburger G, \& Wood NW (2004) Hereditary early-onset Parkinson's disease caused by mutations in PINK1. Science, 304, 1158-1160.

[315] Beilina A, Van Der Brug M, Ahmad R, Kesavapany S, Miller DW, Petsko GA, \& Cookson MR (2005) Mutations in pten-induced putative kinase 1 associated with recessive parkinsonism have differential effects on protein stability. Proc Natl Acad Sci U S A, 102, 5703-5708.

[316] Dagda RK, Cherra SJ, 3rd, Kulich SM, Tandon A, Park D, \& Chu CT (2009) Loss of PINK1 function promotes mitophagy through effects on oxidative stress and mitochondrial fission. J Biol Chem 284, 13843-13855.

[317] Cui M, Tang X, Christian WV, Yoon Y, \& Tieu K (2010) Perturbations in mitochondrial dynamics induced by human mutant PINK1 can be rescued by the mitochondrial division inhibitor mdivi-1. J Biol Chem, 285, 11740-11752.

[318] Lutz AK, Exner N, Fett ME, Schlehe JS, Kloos K, Lammermann K, Brunner B, Kurz-Drexler A, Vogel F, Reichert AS, Bouman L, Vogt-Weisenhorn D, Wurst W, Tatzelt J, Haass C, \& Winklhofer KF (2009) Loss of parkin or PINK1 function increases Drp1-dependent mitochondrial fragmentation. J Biol Chem, 284, 22938-22951.

[319] Sandebring A, Thomas K, Beilina A, van der Brug M, Cleland M, Ahmad R, Miller D, Zambrano I, Cowburn R, Behbahani H, Cedazo-Minguez A, \& Cookson M (2009) Mitochondrial alterations in PINK1 deficient cells are influenced by calcineurin-dependent dephosphorylation of dynamin-related protein 1. Proc Natl Acad Sci US A, 4, e5701.

[320] Gegg ME, Cooper JM, Schapira AH, \& Taanman JW (2009) Silencing of PINK1 expression affects mitochondrial DNA and oxidative phosphorylation in dopaminergic cells. PLoS One, 4, e4756.

[321] Morais VA, Verstreken P, Roethig A, Smet J, Snellinx A, Vanbrabant M, Haddad D, Frezza C, Mandemakers W, VogtWeisenhorn D, Van Coster R, Wurst W, Scorrano L, \& De Strooper B (2009) Parkinson's disease mutations in PINK1 result in decreased complex I activity and deficient synaptic function. EMBO Mol Med, 1, 99-111.

[322] Flinn L, Mortiboys H, Volkmann K, Koster RW, Ingham PW, \& Bandmann O (2009) Complex I deficiency and dopaminergic neuronal cell loss in parkin-deficient zebrafish (danio rerio). Brain, 132, 1613-1623.

[323] Mortiboys H, Thomas KJ, Koopman WJ, Klaffke S, AbouSleiman P, Olpin S, Wood NW, Willems PH, Smeitink JA, Cookson MR, \& Bandmann O (2008) Mitochondrial function and morphology are impaired in parkin-mutant fibroblasts. Ann Neurol, 64, 555-565.

[324] Chien WL, Lee TR, Hung SY, Kang KH, Wu RM, Lee MJ, \& Fu WM (2013) Increase of oxidative stress by a novel PINK1 mutation, P209A. Free Radic Biol Med, 58, 160-169.

[325] Cooper O, Seo H, Andrabi S, Guardia-Laguarta C, Graziotto J, Sundberg M, McLean JR, Carrillo-Reid L, Xie Z, Osborn T, Hargus G, Deleidi M, Lawson T, Bogetofte H, PerezTorres E, Clark L, Moskowitz C, Mazzulli J, Chen L, Volpicelli-Daley L, Romero N, Jiang H, Uitti RJ, Huang Z, Opala G, Scarffe LA, Dawson VL, Klein C, Feng J, Ross OA, Trojanowski JQ, Lee VM, Marder K, Surmeier DJ, Wszolek ZK, Przedborski S, Krainc D, Dawson TM, \& Isacson O (2012) Pharmacological rescue of mitochondrial deficits in iPSC-derived neural cells from patients 
with familial Parkinson's disease. Sci Transl Med, 4, 141190.

[326] Wang D, Qian L, Xiong H, Liu J, Neckameyer WS, Oldham S, Xia K, Wang J, Bodmer R, \& Zhang Z (2006) Antioxidants protect PINK1-dependent dopaminergic neurons in drosophila. Proc Natl Acad Sci US A, 103, 13520-13525.

[327] Hoepken HH, Gispert S, Morales B, Wingerter O, Del Turco D, Mulsch A, Nussbaum RL, Muller K, Drose S, Brandt U, Deller T, Wirth B, Kudin AP, Kunz WS, \& Auburger $\mathrm{G}$ (2007) Mitochondrial dysfunction, peroxidation damage and changes in glutathione metabolism in PARK6. Neurobiol Dis, 25, 401-411.

[328] Park J, Lee SB, Lee S, Kim Y, Song S, Kim S, Bae E, Kim J, Shong M, Kim JM, \& Chung J (2006) Mitochondrial dysfunction in drosophila PINK1 mutants is complemented by parkin. Nature, 441, 1157-1161.

[329] Yang Y, Gehrke S, Imai Y, Huang Z, Ouyang Y, Wang JW, Yang L, Beal MF, Vogel H, \& Lu B (2006) Mitochondrial pathology and muscle and dopaminergic neuron degeneration caused by inactivation of drosophila PINK1 is rescued by parkin. Proc Natl Acad Sci U S A, 103, 1079310798.

[330] Haque ME, Mount M, Safarpour F, Abdel-Messih E, Callaghan S, Mazerolle C, Kitada T, Slack RS, Wallace V, Shen J, Anisman H, \& Park DS (2012) Inactivation of PINK1 gene in vivo sensitizes dopamine-producing neurons to 1-methyl-4-phenyl-1,2,3,6-tetrahydropyridine (MPTP) and can be rescued by autosomal recessive parkinson disease genes, parkin or DJ-1. J Biol Chem, 287, 23162-23170.

[331] Narendra DP, Jin SM, Tanaka A, Suen DF, Gautier CA, Shen J, Cookson MR, \& Youle RJ (2010) PINK1 is selectively stabilized on impaired mitochondria to activate parkin. PLoS Biol, 8, e1000298.

[332] Tang B, Xiong H, Sun P, Zhang Y, Wang D, Hu Z, Zhu Z, Ma H, Pan Q, Xia JH, Xia K, \& Zhang Z (2006) Association of PINK1 and DJ-1 confers digenic inheritance of early-onset Parkinson's disease. Hum Mol Genet, 15, 1816-1825.

[333] Hao LY, Giasson BI, \& Bonini NM (2010) DJ-1 is critical for mitochondrial function and rescues PINK1 loss of function. Proc Natl Acad Sci U S A, 107, 9747-9752.

[334] Dodson MW, \& Guo M (2007) PINK1, parkin, DJ-1 and mitochondrial dysfunction in Parkinson's disease. Curr Opin Neurobiol, 17, 331-337.

[335] Thomas KJ, McCoy MK, Blackinton J, Beilina A, van der Brug M, Sandebring A, Miller D, Maric D, Cedazo-Minguez A, \& Cookson MR (2011) DJ-1 acts in parallel to the PINK1/parkin pathway to control mitochondrial function and autophagy. Hum Mol Genet, 20, 40-50.

[336] Kahle PJ, Waak J, \& Gasser T (2009) DJ-1 and prevention of oxidative stress in Parkinson's disease and other age-related disorders. Free Radic Biol Med, 47, 1354-1361.

[337] Yokota T, Sugawara K, Ito K, Takahashi R, Ariga H, \& Mizusawa H (2003) Down regulation of DJ-1 enhances cell death by oxidative stress, ER stress, and proteasome inhibition. Biochem Biophys Res Commun, 312, 1342-1348.

[338] Xu J, Zhong N, Wang H, Elias JE, Kim CY, Woldman I, Pifl C, Gygi SP, Geula C, \& Yankner BA (2005) The Parkinson's disease-associated DJ-1 protein is a transcriptional co-activator that protects against neuronal apoptosis. Hum Mol Genet, 14, 1231-1241.

[339] Li HM, Niki T, Taira T, Iguchi-Ariga SM, \& Ariga H (2005) Association of DJ-1 with chaperones and enhanced association and colocalization with mitochondrial HSP70 by oxidative stress. Free Radic Res, 39, 1091-1099.
[340] Bader V, Ran Zhu X, Lubbert H, \& Stichel CC (2005) Expression of DJ-1 in the adult mouse CNS. Brain Res, 1041, 102-111.

[341] Bonifati V, Rizzu P, van Baren MJ, Schaap O, Breedveld GJ, Krieger E, Dekker MC, Squitieri F, Ibanez P, Joosse M, van Dongen JW, Vanacore N, van Swieten JC, Brice A, Meco G, van Duijn CM, Oostra BA, \& Heutink P (2003) Mutations in the DJ-1 gene associated with autosomal recessive earlyonset parkinsonism. Science, 299, 256-259.

[342] Taira T, Saito Y, Niki T, Iguchi-Ariga SM, Takahashi K, \& Ariga H (2004) DJ-1 has a role in antioxidative stress to prevent cell death. EMBO Rep, 5, 213-218.

[343] Inden M, Taira T, Kitamura Y, Yanagida T, Tsuchiya D, Takata K, Yanagisawa D, Nishimura K, Taniguchi T, Kiso Y, Yoshimoto K, Agatsuma T, Koide-Yoshida S, Iguchi-Ariga SM, Shimohama S, \& Ariga H (2006) PARK7 DJ-1 protects against degeneration of nigral dopaminergic neurons in Parkinson's disease rat model. Neurobiol Dis, 24, 144-158.

[344] Paterna J, Leng A, Weber E, Feldon J, \& Buëler H (2007) DJ-1 and parkin modulates dopamine-dependent behavior and inhibit mptp-induced nigral dopamine neuron loss in mice. Mol Therapy, 15, 698-704.

[345] Blackinton J, Kumaran R, van der Brug MP, Ahmad R, Olson L, Galter D, Lees A, Bandopadhyay R, \& Cookson MR (2009) Post-transcriptional regulation of mRNA associated with DJ-1 in sporadic Parkinson disease. Neurosci Lett, 452, 8-11.

[346] Blackinton J, Lakshminarasimhan M, Thomas KJ, Ahmad R, Greggio E, Raza AS, Cookson MR, \& Wilson MA (2009) Formation of a stabilized cysteine sulfinic acid is critical for the mitochondrial function of the parkinsonism protein DJ-1. J Biol Chem, 284, 6476-6485.

[347] Lev N, Barhum Y, Pilosof NS, Ickowicz D, Cohen HY, Melamed E, \& Offen D (2013) DJ-1 protects against dopamine toxicity: Implications for Parkinson's disease and aging. J Gerontol A Biol Sci Med Sci, 68, 215-225.

[348] Mullett SJ, Di Maio R, Greenamyre JT, \& Hinkle DA (2012) $\mathrm{Dj}-1$ expression modulates astrocyte-mediated protection against neuronal oxidative stress. J Mol Neurosci, 49, 507511.

[349] Mullett SJ, \& Hinkle DA (2009) DJ-1 knock-down in astrocytes impairs astrocyte-mediated neuroprotection against rotenone. Neurobiol Dis, 33, 28-36

[350] Goldberg JA, Guzman JN, Estep CM, Ilijic E, Kondapalli J, Sanchez-Padilla J, \& Surmeier DJ (2012) Calcium entry induces mitochondrial oxidant stress in vagal neurons at risk in Parkinson's disease. Nat Neurosci, 15, 1414-1421.

[351] Kim RH, Smith PD, Aleyasin H, Hayley S, Mount MP, Pownall S, Wakeham A, You-Ten AJ, Kalia SK, Horne P, Westaway D, Lozano AM, Anisman H, Park DS, \& Mak TW (2005) Hypersensitivity of DJ-1 - deficient mice to 1 - methyl - 4 - phenyl - 1, 2, 3, 6 -tetrahydropyrindine (MPTP) and oxidative stress. Proc Natl Acad Sci U S A, 102, 5215-5220.

[352] Kim SJ, Park YJ, Hwang IY, Youdim MB, Park KS, \& Oh YJ (2012) Nuclear translocation of DJ-1 during oxidative stress-induced neuronal cell death. Free Radic Biol Med, 53, 936-950.

[353] Chen L, Cagniard B, Mathews T, Jones S, Koh HC, Ding Y, Carvey PM, Ling Z, Kang UJ, \& Zhuang X (2005) Agedependent motor deficits and dopaminergic dysfunction in DJ-1 null mice. J Biol Chem, 280, 21418-21426.

[354] Andres-Mateos E, Perier C, Zhang L, Blanchard-Fillion B, Greco TM, Thomas B, Ko HS, Sasaki M, Ischiropoulos H, Przedborski S, Dawson TM, \& Dawson VL (2007) DJ-1 gene deletion reveals that DJ-1 is an atypical peroxiredoxin- 
like peroxidase. Proc Natl Acad Sci U S A, 104, 1480714812.

[355] Yamaguchi H, \& Shen J (2007) Absence of dopaminergic neuronal degeneration and oxidative damage in aged DJ-1deficient mice. Mol Neurodegene, 2, 10.

[356] Sun SY, An CN, \& Pu XP (2012) DJ-1 protein protects dopaminergic neurons against 6-OHDA/Mg-132-induced neurotoxicity in rats. Brain Res Bull, 88, 609-616.

[357] Meulener MC, Xu K, Thomson L, Ischiropoulos H, \& Bonini NM (2006) Mutational analysis of DJ-1 in drosophila implicates functional inactivation by oxidative damage and aging. Proc Natl Acad Sci U S A, 103, 12517-12522.

[358] Meulener M, Whitworth AJ, Armstrong-Gold CE, Rizzu P, Heutink P, Wes PD, Pallanck LJ, \& Bonini NM (2005) Drosophila DJ-1 mutants are selectively sensitive to environmental toxins associated with Parkinson's disease. Curr Biol, 15, 1572-1577.

[359] van der Brug MP, Blackinton J, Chandran J, Hao LY, Lal A, Mazan-Mamczarz K, Martindale J, Xie C, Ahmad R, Thomas KJ, Beilina A, Gibbs JR, Ding J, Myers AJ, Zhan M, Cai H, Bonini NM, Gorospe M, \& Cookson MR (2008) RNA binding activity of the recessive parkinsonism protein DJ-1 supports involvement in multiple cellular pathways. Proc Natl Acad Sci U S A, 105, 10244-10249.

[360] Park J, Kim SY, Cha GH, Lee SB, Kim S, \& Chung J (2005) Drosophila DJ-1 mutants show oxidative stress-sensitive locomotive dysfunction. Gene, 361, 133-139.

[361] Stefanatos R, Sriram A, Kiviranta E, Mohan A, Ayala V, Jacobs HT, Pamplona R, \& Sanz A (2012) DJ1 beta regulates oxidative stress, insulin-like signaling and development in drosophila melanogaster. Cell Cycle, 11, 3876-3886.

[362] Yang Y, Gehrke S, Haque ME, Imai Y, Kosek J, Yang L, Beal MF, Nishimura I, Wakamatsu K, Ito S, Takahashi R, \& Lu B (2005) Inactivation of drosophila DJ-1 leads to impairments of oxidative stress response and phosphatidylinositol 3-kinase/Akt signaling. Proc Natl Acad Sci U S A, 102, 13670-13675.

[363] Menzies FM, Yenisetti SC, \& Min KT (2005) Roles of drosophila DJ-1 in survival of dopaminergic neurons and oxidative stress. Curr Biol, 15, 1578-1582.

[364] Ved R, Saha S, Westlund B, Perier C, Burnam L, Sluder A, Hoener M, Rodrigues CM, Alfonso A, Steer C, Liu L, Przedborski S, \& Wolozin B (2005) Similar patterns of mitochondrial vulnerability and rescue induced by genetic modification of alpha-synuclein, parkin, and DJ-1 in caenorhabditis elegans. J Biol Chem, 280, 42655-42668.

[365] Junn E, Jang WH, Zhao X, Jeong BS, \& Mouradian MM (2009) Mitochondrial localization of DJ-1 leads to enhanced neuroprotection. J Neurosci Res, 87, 123-129.

[366] Canet-Aviles RM, Wilson MA, Miller DW, Ahmad R, McLendon C, Bandyopadhyay S, Baptista MJ, Ringe D, Petsko GA, \& Cookson MR (2004) The Parkinson's disease protein DJ-1 is neuroprotective due to cysteine-sulfinic acid-driven mitochondrial localization. Proc Natl Acad Sci U S A, 101, 9103-9108.

[367] Kato I, Maita H, Takahashi-Niki K, Saito Y, Noguchi N, Iguchi-Ariga SM, \& Ariga H (2013) Oxidized DJ-1 inhibits p53 by sequestering $\mathrm{p} 53$ from promoters in a DNA-binding affinity-dependent manner. Mol Cell Biol, 33, 340-359.

[368] Zhou W, Zhu M, Wilson MA, Petsko GA, \& Fink AL (2006) The oxidation state of DJ-1 regulates its chaperone activity toward alpha-synuclein. J Mol Biol, 356, 1036-1048.

[369] Akazawa YO, Saito Y, Hamakubo T, Masuo Y, Yoshida Y, Nishio K, Shichiri M, Miyasaka T, Iwanari H, Mochizuki
Y, Kodama T, Noguchi N, \& Niki E (2010) Elevation of oxidized DJ-1 in the brain and erythrocytes of Parkinson disease model animals. Neurosci Lett, 483, 201-205.

[370] Saito Y, Hamakubo T, Yoshida Y, Ogawa Y, Hara Y, Fujimura H, Imai Y, Iwanari H, Mochizuki Y, Shichiri M, Nishio K, Kinumi T, Noguchi N, Kodama T, \& Niki E (2009) Preparation and application of monoclonal antibodies against oxidized DJ-1. Significant elevation of oxidized DJ-1 in erythrocytes of early-stage Parkinson disease patients. Neurosci Lett, 465, 1-5.

[371] Bandopadhyay R, Kingsbury AE, Cookson MR, Reid AR, Evans IM, Hope AD, Pittman AM, Lashley T, Canet-Aviles R, Miller DW, McLendon C, Strand C, Leonard AJ, AbouSleiman PM, Healy DG, Ariga H, Wood NW, Silva R, Revesz T, John AH, \& Andrew JL (2004) The expression of DJ-1 (PARK7) in normal human cns and idiopathic Parkinson's disease. Brain, 127, 420-430.

[372] Zhou W, \& Freed CR (2005) DJ-1 up-regulates glutathione synthesis during oxidative stress and inhibits A53T alphasynuclein toxicity. J Biol Chem, 280, 43150-43158.

[373] Huang C, Cheng H, Hao S, Zhou H, Zhang X, Gao J, Sun $\mathrm{QH}, \mathrm{Hu} \mathrm{H}$, \& Wang CC (2006) Heat shock protein 70 inhibits alpha-synuclein fibril formation via interactions with diverse intermediates. J Mol Biol, 364, 323-336.

[374] Klucken J, Shin Y, Masliah E, Hyman BT, \& McLean PJ (2004) HSP70 reduces alpha-synuclein aggregation and toxicity. J Biol Chem 279, 25497-25502.

[375] Ishikawa S, Tanaka Y, Takahashi-Niki K, Niki T, Ariga H, \& Iguchi-Ariga SM (2012) Stimulation of vesicular monoamine transporter 2 activity by DJ-1 in SH-SY $5 Y$ cells. Biochem Biophys Res Commun, 421, 813-818.

[376] Wang X, Petrie TG, Liu Y, Liu J, Fujioka H, \& Zhu X (2012) Parkinson's disease-associated DJ-1 mutations impair mitochondrial dynamics and cause mitochondrial dysfunction. $J$ Neurochem, 121, 830-839.

[377] Krebiehl G, Ruckerbauer S, Burbulla LF, Kieper N, Maurer B, Waak J, Wolburg H, Gizatullina Z, Gellerich FN, Woitalla D, Riess O, Kahle PJ, Proikas-Cezanne T, \& Kruger R (2010) Reduced basal autophagy and impaired mitochondrial dynamics due to loss of Parkinson's disease-associated protein DJ-1. PLoS One, 5, e9367.

[378] Irrcher I, Aleyasin H, Seifert EL, Hewitt SJ, Chhabra S, Phillips M, Lutz AK, Rousseaux MW, Bevilacqua L, JahaniAsl A, Callaghan S, MacLaurin JG, Winklhofer KF, Rizzu P, Rippstein P, Kim RH, Chen CX, Fon EA, Slack RS, Harper ME, McBride HM, Mak TW, \& Park DS (2010) Loss of the Parkinson's disease-linked gene DJ-1 perturbs mitochondrial dynamics. Hum Mol Genet, 19, 37343746.

[379] Irrcher I, Aleyasin H, Seifert EL, Hewitt SJ, Chhabra S, Phillips M, Lutz AK, Rousseaux MW, Bevilacqua L, JahaniAsl A, Callaghan S, MacLaurin JG, Winklhofer KF, Rizzu P, Rippstein P, Kim RH, Chen CX, Fon EA, Slack RS, Harper ME, McBride HM, Mak TW, \& Park DS (2010) Loss of the Parkinson's disease-linked gene DJ-1 perturbs mitochondrial dynamics. Hum Mol Genet, 19, 3734-3746.

[380] Clements CM, McNally RS, Conti BJ, Mak TW, \& Ting JP (2006) DJ-1, a cancer- and Parkinson's disease-associated protein, stabilizes the antioxidant transcriptional master regulator Nrf2. Proc Natl Acad Sci U S A, 103, 15091-15096.

[381] Im JY, Lee KW, Woo JM, Junn E, \& Mouradian MM (2012) DJ-1 induces thioredoxin 1 expression through the Nrf2 pathway. Hum Mol Genet, 21, 3013-3024.

[382] Junn E, Taniguchi H, Jeong BS, Zhao X, Ichijo H, \& Mouradian MM (2005) Interaction of DJ-1 with Daxx inhibits 
apoptosis signal-regulating kinase 1 activity and cell death. Proc Natl Acad Sci U S A, 102, 9691-9696.

[383] Im JY, Lee KW, Junn E, \& Mouradian MM (2010) DJ-1 protects against oxidative damage by regulating the thioredoxin/Ask1 complex. Neurosci Res, 67, 203-208.

[384] Lee KW, Zhao X, Im JY, Grosso H, Jang WH, Chan TW, Sonsalla PK, German DC, Ichijo H, Junn E, \& Mouradian MM (2012) Apoptosis signal-regulation kinase 1 mediates MPTP toxicity and regulates glial activation. Proc Natl Acad Sci U S A, 7, e29935.

[385] White LR, Toft M, Kvam SN, Farrer MJ, \& Aasly JO (2007) MAPK-pathway activity, LRRK2 G2019S, and Parkinson's disease. J Neurosci Res, 85, 1288-1294.

[386] West AB, Moore DJ, Choi C, Andrabi SA, Li X, Dikeman D, Biskup S, Zhang Z, Lim KL, Dawson VL, \& Dawson TM (2007) Parkinson's disease-associated mutations in LRRK2 link enhanced GTP-binding and kinase activities to neuronal toxicity. Hum Mol Genet, 16, 223-232.

[387] Jaleel M, Nichols RJ, Deak M, Campbell DG, Gillardon F, Knebel A, \& Alessi DR (2007) LRRK2 phosphorylates moesin at threonine-558: Characterization of how Parkinson's disease mutants affect kinase activity. Biochem J, $\mathbf{4 0 5}$, 307-317.

[388] Guo L, Gandhi PN, Wang W, Petersen RB, Wilson-Delfosse AL, \& Chen SG (2007) The Parkinson's disease-associated protein, leucine-rich repeat kinase 2 (LRRK2), is an authentic GTPase that stimulates kinase activity. Exp Cell Res, $\mathbf{3 1 3}$, 3658-3670.

[389] Zimprich A, Biskup S, Leitner P, Lichtner P, Farrer M, Lincoln S, Kachergus J, Hulihan M, Uitti RJ, Calne DB, Stoess AJ, Pfeiffer RF, Patenge N, Carbajal IC, Vieregge P, Asmus F, Muller-Myhsok B, Dickson DW, Meitinger T, Strom TM, Wszolek ZK, \& Gasser T (2004) Mutations in LRRK2 cause autosomal-dominant parkinsonism with pleomorphic pathology. Neuron, 44, 601-607.

[390] Paisan-Ruiz C, Jain S, Evans EW, Gilks WP, Simon J, van der Brug M, Lopez de Munain A, Aparicio S, Gil AM, Khan N, Johnson J, Martinez JR, Nicholl D, Carrera IM, Pena AS, de Silva R, Lees A, Marti-Masso JF, Perez-Tur J, Wood NW, \& Singleton AB (2004) Cloning of the gene containing mutations that cause PARK8-linked Parkinson's disease. Neuron, 44, 595-600.

[391] Hodges JR, Davies RR, Xuereb JH, Casey B, Broe M, Bak TH, Kril JJ, \& Halliday GM (2004) Clinico pathological correlates in fronto temporal dementia. Ann Neurol, 56, 399406.

[392] Katchanov J, Harms C, Gertz K, Hauck L, Waeber C, Hirt L, Priller J, von Harsdorf R, Bruck W, Hortnagl H, Dirnagl U, Bhide PG, \& Endres M (2001) Mild cerebral ischemia induces loss of cyclin-dependent kinase inhibitors and activation of cell cycle machinery before delayed neuronal cell death. J Neurosci, 21, 5045-5053.

[393] Biskup S, Moore D, Celsi F, Higashi S, West AB, Andrab SA, Kurkinen K, Yu SW, Savitt JM, Waldvogel HJ, Faull RL, Emson PC, Torp R, Ottersen OP, Dawson TM, \& Dawson VL (2006) Localization of LRRK2 to membranous and vesicular structures in mammalian brain. Ann Neurol, 60, 557-569.

[394] Iaccarino C, Crosio C, Vitale C, Sanna G, Carri MT, \& Barone P (2007) Apoptotic mechanisms in mutant LRRK2mediated cell death. Hum Mol Genet, 16, 1319-1326

[395] Heo HY, Park JM, Kim CH, Han BS, Kim KS, \& Seol W (2010) LRRK2 enhances oxidative stress-induced neurotoxicity via its kinase activity. Exp Cell Res, 316, 649656.
[396] Nguyen HN, Byers B, Cord B, Shcheglovitov A, Byrne J, Gujar P, Kee K, Schule B, Dolmetsch RE, Langston W, Palmer TD, \& Pera RR (2011) LRRK2 mutant ipsc-derived DA neurons demonstrate increased susceptibility to oxidative stress. Cell Stem Cell, 8, 267-280.

[397] Niu J, Yu M, Wang C, \& Xu Z (2012) Leucine-rich repeat kinase 2 disturbs mitochondrial dynamics via dynamin-like protein. $J$ Neurochem, 122, 650-658.

[398] Angeles DC, Gan BH, Onstead L, Zhao Y, Lim KL, Dachsel J, Melrose H, Farrer M, Wszolek ZK, Dickson DW, \& Tan EK (2011) Mutations in LRRK2 increase phosphorylation of peroxiredoxin 3 exacerbating oxidative stress-induced neuronal death. Hum Mutat, 32, 1390-1397.

[399] Saha S, Guillily MD, Ferree A, Lanceta J, Chan D, Ghosh J, Hsu CH, Segal L, Raghavan K, Matsumoto K, Hisamoto N, Kuwahara T, Iwatsubo T, Moore L, Goldstein L, Cookson M, \& Wolozin B (2009) LRRK2 modulates vulnerability to mitochondrial dysfunction in caenorhabditis elegans. $J$ Neurosci, 29, 9210-9218.

[400] Ng CH, Mok SZ, Koh C, Ouyang X, Fivaz ML, Tan EK, Dawson VL, Dawson TM, Yu F, \& Lim KL (2009) Parkin protects against LRRK2 G2019S mutant-induced dopaminergic neurodegeneration in drosophila. J Neurosci, 29, 11257-11262.

[401] Yang D, Li T, Liu Z, Arbez N, Yan J, Moran TH, Ross CA, \& Smith WW (2012) LRRK2 kinase activity mediates toxic interactions between genetic mutation and oxidative stress in a drosophila model: Suppression by curcumin. Neurobiol Dis, 47, 385-392.

[402] Ortiz-Ortiz MA, Moran JM, Ruiz-Mesa LM, Niso-Santano M, Bravo-SanPedro JM, Gomez-Sanchez R, Gonzalez-Polo RA, \& Fuentes JM (2010) Curcumin exposure induces expression of the Parkinson's disease-associated leucinerich repeat kinase 2 (LRRK2) in rat mesencephalic cells. Neurosci Lett, 468, 120-124.

[403] Andres-Mateos E, Mejias R, Sasaki M, Li X, Lin BM, Biskup S, Zhang L, Banerjee R, Thomas B, Yang L, Liu G, Beal MF, Huso DL, Dawson TM, \& Dawson VL (2009) Unexpected lack of hypersensitivity in LRRK2 knock-out mice to MPTP (1-methyl-4-phenyl1,2,3,6-tetrahydropyridine). J Neurosci, 29, 15846-15850.

[404] Fahn S, Oakes D, Shoulson I, Kieburts K, Rudolph A, Lang A, Olanow W, Tanner C, \& Marek K (2004) Levodopa and the progression of Parkinson's disease. N Engl J Med, 351, 2498-2508.

[405] Fahn S, \& Parkinson Study G (2005) Does levodopa slow or hasten the rate of progression of Parkinson's disease? $J$ Neurol, 252(Suppl 4), IV37-IV42.

[406] Olanow CW, Jenner P, \& Brooks D (1998) Dopamine agonists and neuroprotection in Parkinson's disease. Ann Neirol, 44, S167-S174.

[407] Zou L, Jankovic J, Rowe DB, Xie W, Appel SH, \& Le W (1999) Neuroprotection by pramipexole against dopamineand levodopa-induced cytotoxicity. Life Sci, 64, 1275-1285.

[408] Zou L, Xu J, Jankovic J, He Y, Appel SH, \& Le W (2000) Pramipexole inhibits lipid peroxidation and reduces injury in the substantia nigra induced by the dopaminergic neurotoxin 1-methyl-4-phenyl-1,2,3,6-tetrahydropyridine in C57BL/6 mice. Neurosci Lett, 28, 167-170.

[409] Le WD, Jankovic J, Xie W, \& Appel SH (2000) Antioxidant property of pramipexole independent of dopamine receptor activation in neuroprotection. J Neural Transm, 107, 11651173.

[410] Cassarino DS, Fall C, Smith TS, \& Bennett, JP, Jr. (1998) Pramipexole reduces reactive oxygen species production 
in vivo and in vitro and inhibits the mitochondrial permeability transition produced by the parkinsonian neurotoxin methylpyridiniumion. J Neurochem, 71, 295-301.

[411] Tanaka K, Miyazaki I, Fujita N, Haque ME, Asanuma M, \& Ogawa N (2001) Molecular mechanism in activation of glutathione system by ropinirole, a selective dopamine D2 agonist. Neurochem Res, 26, 31-36.

[412] Iida M, Miyazaki I, Tanaka K, Kabuto H, Iwata-Ichikawa E, \& Ogawa N (1999) Dopamine D2 receptor-mediated antioxidant and neuroprotective effects of ropinirole, a dopamine agonist. Brain Res, 838, 51-59.

[413] Parkinson Study G (2000) A randomized controlled trial comparing pramipexole with levopoda in early Parkinson's disease: Design and methods of the calm-pd study. Clin Neuropharmacol, 23, 34-44.

[414] Whone AL, Watts RL, Stoessl AJ, Davis M, Reske S, Nahmias C, Lang AE, Rascol O, Ribeiro MJ, Remy P, Poewe WH, Hauser RA, \& Brooks DJ (2003) Slower progression of Parkinson's disease with ropinirole versus levopoda: The real-pet study. Ann Neurol, 54, 93-101.

[415] Morrish PK (2003) How valid is dopamine transporter imaging as a surrogate marker in research trials in Parkinson's disease? Mov Disord, 18(Suppl 7), S63-S70.

[416] Lees AJ, Katzenschlager R, Head J, \& Ben-Shlomo Y (2001) Ten-year follow-up of three different initial treatments in de-novo PD: A randomized trial. Neurology, 57, 16871694.

[417] Parkinson Study G (2002) Dopamine transporter brain imaging to assess the effects of pramipexole vs levodopa on Parkinson disease progression. JAMA, 287, 1653-1661.

[418] Rakshi JS, Pavese N, Uema T, Ito K, Morrish PK, Bailey DL, \& Brooks DJ (2002) A comparison of the progression of early Parkinson's disease in patients started on ropinirole or L-dopa: An 18F-dopa pet study. J Neural Transm, 109, 1433-1443.

[419] Parkinson Study G (1992) Bromocriptine lessens the incidence of mortality in L-dopa-treated parkinsonian patients: Prado-study discontinued. Eur J Clin Pharmacol, 43, 357563.

[420] Hely M, Morris J, Traficante R, Reid W, O'Sullivan D, \& Williamson P (1999) The Sydney multicentre study of Parkinson's disease: Progression and mortality at 10 years. J Neurol Neurosurg Psychiatry, 67, 300-307.

[421] Montastruc JL, Desboeuf K, Lapeyre-Mestre M, Senard JM, Rascol O, \& Brefel-Courbon C (2001) Long-term mortality results of the randomized controlled study comparing bromocriptine to which levodopa was later added with levodopa alone in previously untreated patients with Parkinson's disease. Mov Disord, 16, 511-514.

[422] Rinne UK, Bracco F, Chouza C, Dupont E, Gershanik O, Marti Masso JF, Montastruc JL, \& Marsden CD (1998) Early treatment of Parkinson's disease with cabergoline delays the onset of motor complications. Results of a double-blind levodopa controlled trial. The PKDS009 study group. Drugs, 55, 23-30.

[423] Barone P, Bravi D, Bermejo-Pareja F, Marconi R, Kulisevsky J, Malagù S, Weiser R, \& Rost N (1999) Pergolide monotherapy in the treatment of early PD: A randomized, controlled study. Pergolide monotherapy study group. $\mathrm{Neu}$ rology, 53, 573-579.

[424] Parkinson Study G (1997) Safety and efficacy of pramipexole in early Parkinson disease. A randomized dose-ranging study. JAMA, 278, 125-130.

[425] Adler CH, Sethi KD, Hauser RA, Davis TL, Hammerstad JP, Bertoni J, Taylor RL, Sanchez-Ramos J, \& O'Brien CF
(1997) Ropinirole for the treatment of early Parkinson's disease. The ropinirole study group. Neurology, 49, 393-399.

[426] Jenner P (2004) Preclinical evidence for neuroprotection with monoamine oxidase-B inhibitors in Parkinson's disease. Neurology, 63, 13-22.

[427] Ives NJ, Stowe RL, Marro J, Counsell C, Macleod A, Clarke CE, Gray R, \& Wheatley K(2004) Monoamine oxidase type $\mathrm{B}$ inhibitors in early Parkinson's disease: Meta-analysis of 17 randomised trials involving 3525 patients. BMJ, 329, 593.

[428] Parkinson Study G (2004) A controlled, randomized, delayed-start study of rasagiline in early Parkinson disease. Arch Neurol, 61, 561-566.

[429] Turnbull K, Caslake R, Macleod A, Ives N, Stowe R, \& Counsell C (2005) Monoamine oxidase B inhibitors for early parkinson's disease. Cochrane Database of Systemic Reviews, 1-62.

[430] Mandel S, Weinreb O, Amit T, \& Youdim MB (2005) Mechanism of neuroprotective action of the anti-parkinson drug rasagiline and its derivatives. Brain Res Brain Res Rev, 48, 379-387.

[431] Shoulson I (1998) Datatop: A decade of neuroprotective inquiry. Parkinson study group. Deprenyl and tocopherol antioxidative therapy of parkinsonism. Ann Neurol, 44, 160166.

[432] Olanow CW, Hauser RA, Jankovic J, Langston W, Lang A, Poewe W, Tolosa E, Stocchi F, Melamed E, Eyal E, \& Rascol O (2008) A randomized, double-blind, placebo-controlled, delayed start study to assess rasagiline as a disease modifying therapy in Parkinson's disease (the adagio study): Rationale, design, and baseline characteristics. Mov Disord, 23, 2194-2201.

[433] Stern MB, Marek KL, Friedman J, Hauser RA, LeWitt PA, Tarsy D, \& Olanow CW (2004) Double-blind, randomized, controlled trial of rasagiline as monotherapy in early Parkinson's disease patients. Mov Disord, 19, 916-923.

[434] Am OB, Amit T, \& Youdim MBH (2004) Contrasting neuroprotective and neurotoxic actions of respective metabolites of anti-Parkinson drugs rasagiline and selegiline. Neurosci Lett, 355, 169-172.

[435] Abu-Raya S, Tabakman R, Blaugrund E, Trembovler V, \& Lazarovici P (2002) Neuroprotective and neurotoxic effects of monoamine oxidase-B inhibitors and derived metabolites under ischemia in PC12 cells. Eur J Clin Pharmacol, 434, 109-116.

[436] Binda C, Milczek EM, Bonivento D, Wang J, Mattevi A, \& Edmondson DE (2011) Lights and shadows on monoamine oxidase inhibition in neuroprotective pharmacological therapies. Curr Top Med Chem, 11, 2788-2796.

[437] Dedeoglu A, Kubilus JK, Yang L, Ferrante KL, Hersch SM, Beal MF, \& Ferrante RJ (2003) Creatine therapy provides neuroprotection after onset of clinical symptoms in Huntington's disease transgenic mice. J Neurochem, 85, 13591367.

[438] Klunk WE (1996) Phosphocreatine-dependent glutamate uptake by synaptic vesicles. A comparison with ATP-dependent glutamate uptake. J Biol Chem, 271, 1343513440.

[439] Lawler JM, Barnes WS, Wu G, Song W, \& Demaree S (2002) Direct antioxidant properties of creatine. Biochem Biophys Res Commun, 290, 47-52.

[440] Matthews RT, Ferrante R, Klivenyi P, Yang L, Klein A, Mueller G, Kaddurah-Daouk R, \& Beal MF (1999) Creatine and cyclocreatine attenuate MPTP neurotoxicity. Exp Neur, 157, 142-149. 
[441] Bender A, Koch W, Elstner M, Schombacher Y, Bender J, Moeschl M, Gekeler F, Muller-Myhsok B, Gasser T, Tatsch T, \& Klopstock T (2006) Creatine supplementation in Parkinson disease: A placebo-controlled randomized pilot trial. Neurology, 67, 1262-1264.

[442] NINDS, NET-PDI (2006) A randomized, double-blind, futility clinical trial of creatine and minocycline in early Parkinson disease. Neurology, 14, 664-671.

[443] NINDS, NET-PDI (2008) A pilot clinical trial of creatine and minocycline in early Pparkinson disease: 18 -month results. Clin Neuropharmacol, 31, 141-150.

[444] Elm JJ, NINDS, NET-PDI (2012) Design innovations and baseline findings in a long-term Parkinson's trial: The national institute of neurological disorders and stroke exploratory trials in Parkinson's disease long-term study-1. Mov Disord, 27, 1513-1521.

[445] Fahn S (1992) A pilot trial of high-dose alpha-tocopherol and ascorbate in early Parkinson's disease. Ann Neurol, 32, S128-S132.

[446] Etminan M, Gill SS, \& Samii A (2005) Intake of vitamin E, vitamin C, and carotenoids and the risk of Parkinson's disease: A meta-analysis. Lancet Neurol, 4, 362-365.

[447] Shults CW, Oakes D, Kieburtz K, Beal MF, Haas R, Plumb S, Juncos JL, Nutt J, Shoulson I, Carter J, Kompoliti K, Perlmutter JS, Reich S, Stern M, Watts RL, Kurlan R, Molho E, Harrison M, Lew M, \& Parkinson Study Group (2002) Effects of coenzyme Q10 in early Parkinson disease: Evidence of slowing of the functional decline. Arch Neurol, 59, $1541-1550$

[448] Investigators NN-P (2007) A randomized clinical trial of coenzyme Q10 and GPI-1485 in early Parkinson disease. Neurology, 68, 20-28.

[449] Chaturvedi RK, \& Beal MF (2013) Mitochondria targeted therapeutic approaches in Parkinson's and Huntington's diseases. Mol Cell Neurosci, 55, 101-114.
[450] Cieslik M, Pyszko J, \& Strosznajder JB (2013) Docosahexaenoic acid and tetracyclines as promising neuroprotective compounds with poly(ADP-ribose) polymerase inhibitory activities for oxidative/genotoxic stress treatment. $\mathrm{Neu}$ rochem Int, 62, 626-636.

[451] Chen LW, Wang Y, Wei LC, Shi M, \& Chan YS (2007) Chinese herbs and herbal extracts for neuroprotection of dopaminergic neurons and potential therapeutic treatment of Parkinson's disease. CNS Neurol Disord Drug Targets, 6 , 273-281.

[452] Cheng B, Lu H, Bai B, \& Chen J (2013) D-betahydroxybutyrate inhibited the apoptosis of PC12 cells induced by $\mathrm{H} 2 \mathrm{O} 2$ via inhibiting oxidative stress. Neurochem Int, 62, 620-625.

[453] Holmer HK, Keyghobadi M, Moore C, Menashe RA, \& Meshul CK (2005) Dietary restriction affects striatal glutamate in the MPTP-induced mouse model of nigrostriatal degeneration. Synapse, 57, 10-112.

[454] Maswood N, Young J, Tilmont E, Zhang Z, Gash DM, Gerhardt GA, Grondin R, Roth GS, Mattison J, Lane MA, Carson RE, Cohen RM, Mouton PR, Quigley C, Mattson MP, \& Ingram DK (2004) Caloric restriction increases neurotrophic factor levels and attenuates neurochemical and behavioral deficits in a primate model of Parkinson's disease. Proc Natl Acad Sci U S A, 101, 18171-18176.

[455] Duan W, \& Mattson MP (1999) Dietary restriction and 2deoxyglucose administration improve behavioral outcome and reduce degeneration of dopaminergic neurons in models of Parkinson's disease. J Neurosci Res, 57, 195-206.

[456] Vanitallie TB, Nonas C, Di Rocco A, Boyar K, Hyams K, \& Heymsfield SB (2005) Treatment of Parkinson disease with diet-induced hyperketonemia: A feasibility study. Neurology, 64, 728-730. 